\title{
Ceramide Metabolism Enzymes-Therapeutic Targets against Cancer
}

\author{
Ana Gomez-Larrauri ${ }^{1,2}$, Upasana Das Adhikari ${ }^{3,4}$, Marta Aramburu-Nuñez ${ }^{5}\left(\mathbb{D}\right.$, Antía Custodia ${ }^{5}$ and \\ Alberto Ouro $5, *$ (D)
}

1 Department of Biochemistry and Molecular Biology, Faculty of Science and Technology,

University of the Basque Country, P.O. Box 644, 48980 Bilbao, Spain; ana.gomezlarrauri@osakidetza.eus

2 Respiratory Department, Cruces University Hospital, P.O. Box 644, 48903 Barakaldo, Spain

3 Ragon Institute of MGH, MITHarvard and HarvardMIT, Cambridge, MA 02139, USA; upasana.da@gmail.com

4 Harvard Medical School, Boston, MA 02114, USA

5 Clinical Neurosciences Research Laboratories, Health Research Institute of Santiago de Compostela (IDIS), Travesa da Choupana s/n, 15706 Santiago de Compostela, Spain; marta.aramburu.nunez@sergas.es (M.A.-N.); antia.custodia.malvido@sergas.es (A.C.)

* Correspondence: alberto.ouro.villasante@sergas.es; Tel.: +34-664-326-589

Citation: Gomez-Larrauri, A.; Das Adhikari, U.;

Aramburu-Nuñez, M.; Custodia, A.; Ouro, A. Ceramide Metabolism Enzymes-Therapeutic Targets against Cancer. Medicina 2021, 57, 729. https://doi.org/10.3390/

medicina57070729

Academic Editor: Udo Schumacher

Received: 27 June 2021

Accepted: 13 July 2021

Published: 19 July 2021

Publisher's Note: MDPI stays neutral with regard to jurisdictional claims in published maps and institutional affiliations.

Copyright: (c) 2021 by the authors. Licensee MDPI, Basel, Switzerland. This article is an open access article distributed under the terms and conditions of the Creative Commons Attribution (CC BY) license (https:/ / creativecommons.org/licenses/by/ $4.0 /)$.

\begin{abstract}
Sphingolipids are both structural molecules that are essential for cell architecture and second messengers that are involved in numerous cell functions. Ceramide is the central hub of sphingolipid metabolism. In addition to being the precursor of complex sphingolipids, ceramides induce cell cycle arrest and promote cell death and inflammation. At least some of the enzymes involved in the regulation of sphingolipid metabolism are altered in carcinogenesis, and some are targets for anticancer drugs. A number of scientific reports have shown how alterations in sphingolipid pools can affect cell proliferation, survival and migration. Determination of sphingolipid levels and the regulation of the enzymes that are implicated in their metabolism is a key factor for developing novel therapeutic strategies or improving conventional therapies. The present review highlights the importance of bioactive sphingolipids and their regulatory enzymes as targets for therapeutic interventions with especial emphasis in carcinogenesis and cancer dissemination.
\end{abstract}

Keywords: ceramide (Cer); sphingolipids (Sphs); cancer; ceramide 1-phosphate (C1P); shingosine 1-phosphate (S1P); deoxy-sphingolipids; apoptosis; cell proliferation

\section{Introduction}

Sphingolipids are fundamental components of cell membranes. They were discovered in brain extracts by J. L. W. Thudichum in 1876 and were considered merely as structural molecules of cell architecture. It was not until 1986 when Hannun and co-workers demonstrated that some sphingolipids were bioactive molecules, showing that sphingosine was capable of inhibiting protein kinase C (PKC) [1]. Since then, many sphingolipids have been shown to play critical roles in cell activation and the control of cell and tissue homeostasis [2-4]. Among all of the sphingolipids that are present in the organism, sphingosine and ceramide, together with their phosphorylated forms sphingosine-1-phosphate (S1P) and ceramide-1-phosphate (C1P), are crucial regulators of cell physiology and pathology $[5,6]$.

So far, more than 30 enzymes involved in sphingolipid metabolism have been characterized. These enzymes are highly regulated and are involved in the regulation of relevant pathophysiologic processes. Dysfunction of these enzymes may cause decompensation of the concentrations of their sphingolipid products, leading to a loss of cellular homeostasis. An important aspect that demonstrates the specificity and importance of sphingolipids in cell physiology is that small variations in sphingolipid concentrations can lead to or be a consequence of disease [4]. Among the most important sphingolipids are ceramide (Cer), 
sphingosine (Sph) and their phosphorylated forms, C1P and S1P. The intracellular concentrations of these metabolites define a precise balance that eventually determines cellular actions and fate. Whilst Cer and Sph are proapoptotic, C1P and S1P are proliferative and anti-apoptotic signals [4]. Sph is the precursor of S1P through phosphorylation by sphingosine kinases 1 and 2 (SphK1 and SphK2) [7,8], whereas C1P is produced by the action of CerK. Whether CerK exists as a sole gene product or as a family of different isoforms awaits further investigation. CerK resides in the Golgi apparatus, where it can phosphorylate ceramide that is transported by ceramide transfer protein (CERT) from the ER to the Golgi. Noteworthily, CerK-generated C1P can be transported by a recently identified C1P transfer protein (CPTP) from the Golgi to the plasma membrane, where it might participate in signal transduction processes [9]. Although CerK has also been identified in plants [10], it is the only enzyme capable of generating C1P in mammalian cells [11]. As mentioned above, an appropriate equilibrium between sphingosine and ceramide, versus their phosphorylated forms, can determine cell function and fate (Figure 1). When this balance is disturbed or altered, disease may arise. In particular, many inflammatory processes and pathologies, including cardiovascular diseases, neurodegenerative disorders, lung inflammatory disorders (such as chronic obstructive pulmonary disease (COPD) or asthma) type 2 diabetes or cancer, are characterized by disruption of sphingolipid homeostasis [12-21]. Moreover, it has been reported that treatment with short-chain Cer anologs is an effective treatment against certain cancers [22-24]. In addition, deoxy-sphingolipids have been shown to be of great importance when observing their potential as regulators of sphingolipid metabolism.
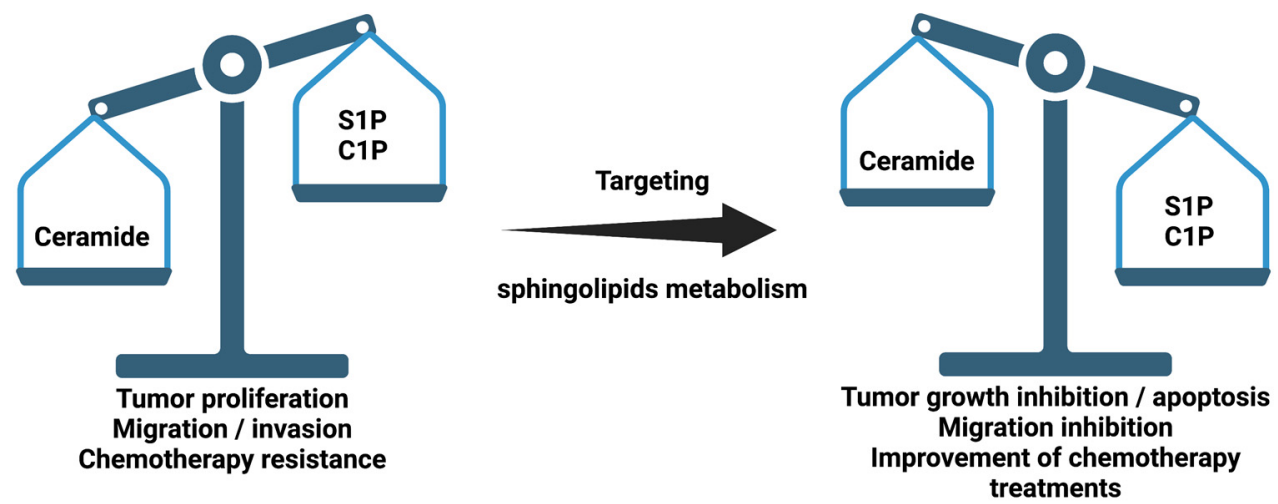

Figure 1. Schematic representation of sphingolipid ratio and their relationship with cancer. Sphingosine 1-phosphate (S1P) and ceramide 1-phosphate (C1P).

\section{Sphingolipid Metabolism}

Cer is considered the central hub of sphingolipid metabolism. It has a dual role in cell biology as it can act as a precursor of complex sphingolipids or as second messengers to regulate a variety of physiologic and pathologic processes. In particular, it is well established that ceramides can induce cell cycle arrest and are potent inducers of apoptotic cell death $[3,25]$. As mentioned above, there are more than 30 enzymes involved in Cer metabolism, with a high degree of conservation and strict regulation. Ceramides can be mainly synthesized by three different pathways (Figure 2).

The de novo pathway occurs integrally in the endoplasmic reticulum; it begins with the action of serine palmitoyl transferase (SPT) acting on palmitate and serine to form 3-ketosphinganine (or 3-ketodihydrosphingosine). The SPT complex is constituted by SPTLC1, SPTLC2, ssSPTa/b (two small subunits that enhance enzyme activity and also specify the acyl-CoA substrate) and four regulatory subunits, called ORMDLs (homologs of the yeast and plant Orms) [26]. Interestingly, recent studies have shown the efficiency of oral SPT inhibitors as anticancer drugs $[27,28]$. 3-ketodihydrosphingosine is then acted upon by 3-keto-dihydrosphingosine reductase (KDR), producing sphinganine. Ceramide synthase (CerS) can then catalyze the formation of dihydroceramides (dhCer) through the incorporation of acyl-CoA of different chain lengths. The last step of this pathway is 
catalyzed by a desaturase (Des1), which will introduce a trans double bond in position 4-5 $(\triangle 4 \mathrm{E})$ of dhCer to produce ceramide. In particular, specific deletion of this gene and polymorphisms are associated with the reduction of hepatic steatosis, attenuation of insulin and cognitive impairment in schizophrenia and with hypomyelination, leukodystrophy and degeneration of nervous system [29-33]. Of interest, the fatty acid desaturase family protein FADS3 has recently been described as a ceramide desaturase that adds a double bond at the $\Delta 14 \mathrm{Z}$ position [34,35]. This enzyme could be of great importance in diseases related to the functional loss of Des1.

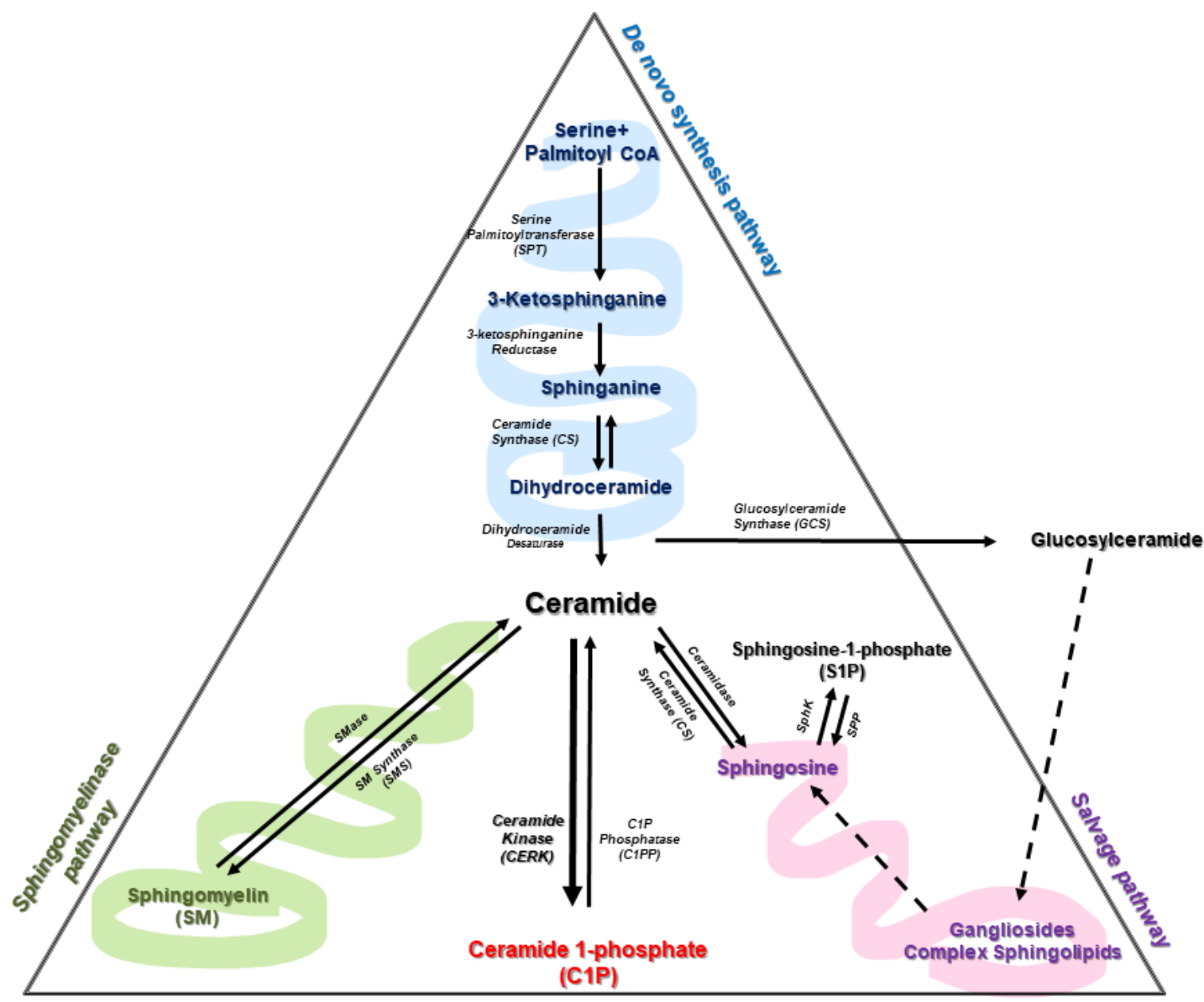

Figure 2. Representation of sphingolipid metabolism with ceramide as the central metabolite. SphK = sphingosine kinase; $\mathrm{SPP}=$ sphingosine-1-phosphate phosphatase and SMase $=$ sphingomyelinase.

The sphingomyelinase (SMase) pathway is a catabolic pathway involving the degradation of sphingomyelin (SM) by the action of sphingomyelinases at the plasma membrane of cells, thereby generating Cer and phosphocholine. Cer formation through this pathway is considerably rapid compared to Cer synthesized de novo. Three major types of SMase exist, and these have been defined according to their optimal $\mathrm{pH}$. These include lysosomal and plasma membrane acid SMase (aSMase), endoplasmic reticulum/nucleus and plasma membrane neutral SMase (nSMase) and alkaline SMase (alk-SMase), the latter being present in the intestinal track and human bile [36,37]. aSMase and nSMase are involved in cell signaling processes, whereas alkaline SMase participates in the digestion of SM incorporated in the diet. Of note, some pro-inflammatory cytokines, such as tumor necrosis factor $\alpha$ (TNF- $\alpha$ ) or interleukin-1 $\beta$ (IL-1 $\beta)$, stimulate SMase activity to increase Cer concentration in cells [38-40]. Furthermore, both aSMase and nSMase activities can be stimulated by some anticancer drugs as part of their mechanism of action and by irradiation of cells with ultraviolet (UV) or ionizing radiation [41]. 
The salvage pathway is also a catabolic pathway. It involves the degradation of complex sphingolipids in acidic compartments, such as lysosomes, through a series of enzymatic reactions that give rise to Cer. The last step comprises the conversion of glucosylceramide by acid $\beta$-glucosidase 1 ( $\beta$-GCase) to Cer. Dysfunction or deficiency of this enzyme leads to the development of lysosomal storage diseases (LSDs) [20].

The Cer is then transported to the cytosol, where ceramide synthases (CerS), which are located in the ER, catalyze the incorporation of acyl-CoAs to form Cer [42]. To date, six different CerS have been described, and these are encoded by six different genes. These enzymes vary in their levels of expression, cell type and their affinity for hydrocarbon chains of different lengths [43]. CerS enzymes have been implicated in different pathologies, chemotherapy resistance and oxidative stress [44-48]. Therefore, CerSs are enzymes also under study for therapeutic use [19]. There are different described enzymes, such as alkaline ceramidases (encoded by ACER1, ACER2 and ACER3), acidic ceramidase (encoded by ASAH1) and neutral ceramidase (encoded by ASAH2) [49-52]. ASAH1 is ubiquitously located in lysosomal compartments, while ASAH2 is expressed in plasma membranes and mainly in the small intestine and colon [49].

One of the most important aspects in cell homeostasis is the balance between the species of Cer, C1P and S1P, which will determine cell fate. In addition to the above pathways, Cer can be interconverted into C1P or S1P by different enzymatic activities.

Sphingosine Kinase (SphK)/S1P phosphatase. A relevant aspect of Sph metabolism is that it can be phosphorylated by sphingosine kinases to form S1P, which is bioactive and can control many physiologic and pathologic processes. Dephosphorylation of S1P to Sph is carried out by specific S1P phosphatases (SPP) or by lipid phosphate phosphatase (LPP) activity (reviewed by Gangoiti et al. [3]), whereas complete breakdown to non-sphingolipid moieties (hexadecenal and phosphoethanolamine) is catalyzed by S1P lyase [53].

CerK and C1P phosphatases. C1P levels are mainly regulated by the actions of Cerk and ceramide phosphate phosphatases (CPP) [54], less specific lipid phosphate phosphateases (LPPs) can also efficiently degrade C1P [55]. Once synthesized, Cer can be transported to Golgi apparatus by ceramide transfer protein (CERT) where it can be phosphorylated by Cerk Moreover, sphingomyelinase phosphodiesterase like 3b (SMPDL3b), an enzyme with high homology to aSMase that is present in podocytes, can also modulate $\mathrm{C} 1 \mathrm{P}$ levels. Podocytes are important components of the renal glomeruli, preventing the leakage of plasma proteins into the urine [56]. This enzyme impedes the access of Cerk to its ceramide substrate thereby also reducing intracellular C1P concentrations [57].

\section{Enzymes of Ceramide Metabolism}

\subsection{The De Novo Pathway of Ceramide Synthesis \\ 3.1.1. Serine Palmitoyl Transferase (SPT)}

Serine palmitoyl transferase (SPT) is a heteromeric enzyme, composed of three subunits, that catalyzes the first step of the de novo ceramide synthesis pathway. The protein is localized to the endoplasmic reticulum. It catalyzes the condensation of L-serine and palmitoyl-coenzyme A to generate 3-keto-sphinganine (Figure 1). Several studies have described an increase in SPT activity in response to chemotherapy and radiotherapy in various types of cancer. So far, some SPT inhibitors that block tumor growth have been described. In particular, myriocin (also known as ISP-1) is a potent SPT inhibitor [58]. It was discovered as an antifungal antibiotic from Myriococcum albomyces [59], and later it was shown to block SPT [60]. Treatment with myriocin caused growth inhibition of breast cancer [19] and B16F10 melanoma cells through G2/M phase arrest [61]. In addition, there is a positive correlation between SPT enzyme inhibition and growth suppression of a human lung adenocarcinoma cell line (HCC4006) [62]. Furthermore, inhibition of SPT with myriocin or knocking down the enzyme expression with a specific siRNA inhibited the proliferation of human U87MG glioblastoma cells, an action that was associated with suppression of intracellular S1P levels [63]. Synthetic molecules of imidazopyridine and pyrazolopiperidine derivatives also showed high affinity and inhibitory capacity for SPT, decreasing ceramides levels in serum by $50 \%$ in mice that were treated orally for one week, 
and they were proposed as potential treatments for diabetes [28]. The authors of the latter report also designed two new inhibitors of SPT, tetrahydropyrazolopyridine and 3-phenylpiperidine. Both of these compounds were able to reduce ceramide concentration in the blood, and they inhibited the proliferation of HCC4006 and PL-21 cells derived from an acute promyelocytic leukemia $[27,64]$.

It has been proposed that the antitumor activity of SPT is caused by increasing the levels of proapoptotic ceramides. In fact, some anticancer drugs exert at least part of their therapeutic effects through the activation of SPT. In particular, fenretinide, a synthetic retinoid and cytotoxic molecule to a variety of cancer cells, increased the concentration of dhCer and Cer, leading to neuroblastoma cell apoptosis, an action that was associated with the interaction of this drug with SPT and DeS1 [65]. Furthermore, a fenretinide metabolite, 4-oxo-fenretinide, markedly induced G2-M cell cycle arrest and apoptosis in ovarian, breast and neuroblastoma tumor cells [66]. Interestingly, naturally occurring resveratrol, a phytoalexin present in grapes and red wine, potently induced growth inhibition and apoptosis in metastatic breast cancer cells via the activation of SPT and accumulation of ceramide [67].

Recently, it has been shown that the SPTLC2 and SPTLC3 subunits have a different affinity for Acyl-CoA in the function of the chain, giving rise to Cer of different lengths, while SPTLC1 is essential to produce an active enzyme $[68,69]$. ssSPT subunits have been described as important regulators of SPT activity. Recently, it has been observed that in patients with prostate cancer treated with anti-androgens treatment, an increase in the expression of SPTSSB was detected [70]. Moreover, administration of exogenous Cer nanoliposomes was determined as an efficient treatment in cancer cells [70]. In addition to ssSPT subunits, the Tsc3 subunit was found to be a potent regulatory protein of SPT, increasing its activity by up to 50 -fold [71,72].

\subsubsection{Ceramide Synthase (CerS)}

CerS takes part in both the de novo pathway and the salvage pathway of ceramide synthesis. CerS is a family of six different isoforms, each of which synthesizes ceramides with different chain lengths of fatty acyl-CoA, resulting in a specific activity. This fact is important, since, for example, CerS1 generates 18-carbon Cer $\left(\mathrm{C}_{18: 0} 0^{-C}\right.$ eramide $)$ that inhibits tumor growth [73], whereas CerS5/ 6 produces $\mathrm{C}_{16: 0}$-Ceramide, an anti-apoptotic metabolite in human head and neck squamous cell carcinomas [74] that is also involved in type II diabetes $[17,33,75]$ and that has proinflammatory properties [76]. Interestingly, a specific inhibitor of CerS1, called P053, has been described to reduce the levels of $\mathrm{C}_{18: 0^{-}}$ Ceramide in renal HEK 293 cancer cells [77]. Overexpression of CerS2 or CerS4 increases very long chain ceramides ( $\mathrm{C}_{24: 0}$-Ceramide), which have a protective effect on human breast and colon cancer [78]. Recently, increased levels of $\mathrm{C}_{24: 0}$-Ceramide in gallbladder cancer was observed due to the overexpression of SPT and CerS2 and related to the progression of the tumor [24].

Interestingly, analogs derived from Fingolimod (FTY720) specifically inhibit isoforms of CerS in HCT-106 and HeLa cells. Specifically, the ST1058 and ST1074 inhibitors preferentially inhibit CerS2 and CerS4, whereas ST1072 blocks the activities of CerS4 and CerS6, and ST1060 inhibits CerS2 [79].

It has also been shown that overexpression of CerS in certain types of cancer confers resistance to chemotherapy [44]. Concerning anticancer drugs, anthracyclines have been shown to increase the content of pro-apoptotic ceramides by stimulating CerS [80]. In particular, vinblastine activated CerS, increasing ceramide content in the liver [81]; paclitaxel (taxol) is an antitumor molecule that led to Cer-induced apoptosis in human breast cancer cells by activation of both SPT and CerS [82], and antifolate methotrexate (MTX) increased the levels of $\mathrm{C}_{16: 0}$-Ceramide to reduce proliferation in a p53-dependet manner in human lung adenocarcinoma cells [83]. In addition, a recent study showed that the activity of CerS6, giving rise to Cer, increases the inhibitory capacity of p53 to block progeny formation in polyploid cancer cells [84]. By contrast, fumonisin B1, a fungal metabolite that 
potently inhibits CerS, was shown to reduce apoptotic cell death in a variety of cell types, including SCC17B human head and neck squamous carcinoma cells [85].

\subsubsection{Dihydroceramide Desaturase (Des1, also Known as DEGS1)}

Des1 is the last enzyme in the de novo synthesis pathway of ceramide. This enzyme catalyzes the conversion of dhCer to Cer by insertion of a trans double bond in position 4-5. Experiments using heterozygous DES1-null mice showed higher dhCer/Cer ratios in multiple organs, rendering cells resistant to apoptosis [86]. Furthermore, knockdown of Des1 using siRNA [87] led to cell cycle arrest in human neuroblastoma cells [87]. However, accumulation of dhCer in cells can stimulate autophagy. Although autophagy is a mechanism of cancer cell survival, it can also lead to cell death [88-90]. So far, several compounds with the ability to inhibit Des1 have been described. For example, resveratrol, which is a dietary polyphenol with well recognized antioxidant and health beneficial properties, was shown to inhibit Des1, causing autophagy in gastric cancer HGC27 cells [91]. Other Des1 inhibitors, including $\gamma$-tocotrienol, phenoxodiol or celecoxib, induce autophagy by dhCer accumulation in T98G and U87MG glioblastoma cell lines by inhibition of Des1 [88]. Furthermore, 3-ketosphinganine and its dideuterated analog at $\mathrm{C} 4(\mathrm{~d} 2 \mathrm{KSa})$ are metabolized to produce high levels of dihydrosphingolipids (dhSLs) in HGC27, T98G and U87MG cancer cells. d2KSa provokes the accumulation of dhCer and other dhSLs by inhibition of Des1 and induces autophagy in cancer cells [92]. Fenretinide, which is an agonist of SPT, also inhibits Des1 and, combined with Foscan-mediated photodynamic therapy, enhances apoptosis in SCC19 cells, a human head and neck squamous cell carcinoma [93].

$\mathrm{N}$-[(1R,2Shttpo)-2-hydroxy-1-hydroxymethyl-2-(2-tridecyl-1-cyclopropenyl)ethyl]octanamide (GT11) is a specific inhibitor of Des1 that efficiently activates autophagy and apoptosis of the human U87MG glioma cell line. In addition, treatment with tetrahydrocannabinol (THC) produces an alteration of the lipid composition in the endoplasmic reticulum and, along with it, the accumulation of dhCer due to the reduction of Des1 expression, leading to a stimulation of autophagy and apoptosis in human U87MG glioma cells [89]. Moreover, THC treatment or selective inhibition of Des1 by GT11 efficiently activates autophagy and apoptosis and inhibits tumor growth in mice [89].

\subsection{Enzymes of the Sphingomyelinase Pathway}

3.2.1. Sphingomyelinases (SMase)

Based on their optimal $\mathrm{pH}$ for activity and their location, there are three major types of SMases: aSMase, nSMase and Alk-SMase. SMases catalyze the breakdown of membrane SM to ceramide and phosphocholine. Stimulation of SMase activity is related to oxidative stress [36], cell death signals such as TNF Receptor (TNFR) and Fas [94,95] or anticancer drugs [96]. Experiments where SMase activity was knocked down showed inhibition of tumor growth in non-small cell lung carcinomas [97]. Furthermore, aSMase-null mice $\left(s m p d 1^{-/}\right)$were protected from pulmonary tumor metastasis [98]. Contrarily, resveratrol was described to inhibit cell proliferation of human leukemia (K562 cell line) and cancer cells (HCT116 cell line) by up-regulation of aSMase and the consequent Cer accumulation [99].

The term FIASMA (Functional Inhibitor of Acid SphingoMyelinAse) encompasses a family of drugs, many of them approved for use in humans, which have been shown to indirectly inhibit the activity of aSMase [100]. Interestingly, recent studies have shown that inhibition of lysosomal SMase via these inhibitors prevents infection of the SARS-CoV-2 virus [101-103]. In Niemann-Pick disease, it has been observed that aSMase dysfunction leads to a dysregulation of lysosomes, causing a disruption of cholesterol transport [104] This process can lead to cell dysfunction and death. Perphenazine and fluphenazine, both FIASMA members, were found to inhibit xenografted tumor growth by disruption of intracellular cholesterol transport [105].

Recently, a small molecule called ARC39 was synthetized and characterized. ARC39 was found to inhibit both lysosomal and secretory aSMase in vitro with L929, HepG2 and B16F10 cells [106]. However, ARC39 inhibition in vivo could not be confirmed; therefore, more studies should be carried out. Moreover, a potent light-inducible photocaged ASM 
inhibitor (PCAI) with the ability to inhibit aSMase has been developed. Furthermore, being inducible by light, it is addressable [107].

Most studies on the implication of SMase activity in cancer are related to the acidic form of the enzyme, although nSMase may also play an important role in cancer biology [95]. nSMase has also been observed to be involved in the activation and migration of $\mathrm{T}$ cells, responsible for the detection and elimination of cancer cells [108]. Doxorubicin is an antibiotic of the anthracycline family widely used in chemotherapy treatment. Interestingly, doxorubicin-induced growth arrest in breast cancer cells is due to a p53-dependent upregulation of nSMase-2 [96]. As seen above, chemotherapy treatments are highly linked to the metabolism of sphingolipids, sometimes in a good way and others in the opposite direction. Recently, it has been observed that doxorubicin treatment stimulated the activity of aSMase, leading to an increase in Cer and reactive oxygen species (ROS), promoting apoptosis [109]. As a side effect, the release of ROS into the bloodstream damaged the vascular endothelium [109]. Exosomes are vesicles between 40-160 $\mathrm{nm}$ that can be secreted by a variety of cells. They carry nucleic acids, proteins and metabolites. Their function is that of intercellular communication between nearby and distant cells, both in physiological conditions and in certain diseases. In recent years, their involvement as a biomarker and therapeutic target has gained great interest $[110,111]$. Exosomes have been found to be crucial for the formation and maintenance of microenvironments in tumors. The need for nSMase activity for the release of exosomes has been described [110,112]. Therefore, certain studies in tumors have focused on the inhibition of this enzyme. In particular, the nSMase isoform, nSMase2, was involved in exosome miRNA secretion and contributed to cancer cell metastasis through the induction of angiogenesis [113]. Specific inhibition of nSMase by GW4869 showed a potential target to block the metastasis. In addition, low expression of nSMase was found in exosomes from hepatocellular carcinoma patients, related with a poor outcome [114]. Similarly, exosomes have been shown to be signaling systems for the immune system, allowing the fight against tumors. Recently, it has been observed that the treatment with platinium nanoparticles enhanced exosomes secretion in A549 lung cancer cells [115].

\subsubsection{Sphingomyelin Synthase (SMS)}

The sphingomyelin synthase (SMS) family consists of three members, SMS1, SMS2 and SMS-related protein (SMSr) [116]. This enzyme activity catalyzes the synthesis of SM from Cer and phosphatidylcholine, thereby releasing diacylglicerol. It was demonstrated that selective inhibition of SMS by D609 induces an increase in the concentration of ceramide in the ER, and it triggers autophagy in hippocampal neurons [117]. However, in glioblastoma, it was observed that treatment with the 2-hydroxyoleic acid (2OHOA), an anticancer drug, caused an increase in SMS activity. Furthermore, the inhibition with D609 diminishes the anticancer effect [118]. Recently, SMS2 was found to be upregulated in different cancers, such as breast [119] and ovarian [120]. High infiltration of M2-polarized macrophages in primary tumors is related with poor outcomes in patients. Zheng and co-workers demonstrated the disruption of apoptotic pathways by activation of SMS2 in breast cancer [121]. Activation of SMS2 causes a reduction in Cer levels and stimulates cell proliferation through activation of the transforming growth factor- $\beta$ (TGF- $\beta$ )/Smad signaling pathway. By contrast, inhibition of SMS2 by specific siRNA led to accumulation of Cer and the promotion of cell death [121]. In addition, recent works observed that SMS2 is upregulated in breast cancer and induces macrophages polarization and tumor progression [119]. Moreover, SMS2 inhibition by 15w or knockdown reduced the release of cytokines that stimulate macrophage polarization, reducing tumor growth [119]. In addition, SMS1 down regulation was found in metastatic melanoma patients and was associated with worse prognosis due to an imbalance between SM and glucosyl-ceramide levels [122]. 


\subsection{Enzymes of the Salvage Pathway}

\subsubsection{Glucosylceramide Synthase (GCS)}

Glucosylceramide synthase (GCS) is a lysosomal enzyme that introduces a glycosylation on the ceramide to produce glucosylceramide. GCS has been observed to be upregulated in different types of cancer, being associated with resistance to anticancer treatments [123-127]. Glucosylceramide plasma levels have recently been described as a promised biomarker for prostate cancer status [128]. A recent study has demonstrated that a GCS inhibitor, called 1-phenyl-2-decanoylamino-3-morpholino-1-propanol (PDMP), caused a lysosomal lipid accumulation and inactivation of mTOR in HeLa cells, leading to apoptotic stimulation [129].

\subsubsection{Acid $\beta$-Glucosidase ( $\beta$-GCase)}

Mutations in the GBA1 gene that codes for $\beta$-GCase is one of the main causes of the development of Parkinson's disease $[130,131]$. Different studies have associated the deficiency of this gene with the possibility of suffering from certain types of cancer [132,133]. Recently, it was reported that $\beta$-GCase was overexpressed in chemotherapy-resistant gastric cancer cells [134]. In addition, it was observed that its inhibition with specific siRNAs produced a lysosomal dysfunction that, together with anticancer treatment, caused cell death [134].

\subsubsection{Ceramidase}

As seen above, ceramidases catalyze the degradation of ceramide to sphingosine. Ceramidases have been described as important regulators of the processes of cellular autophagy and resistance to chemotherapy. Therefore, inhibition of the different ceramidase isoforms has been shown to be beneficial for the treatment of different types of cancer $[49,52,135]$. In recent years, different inhibitors have been developed that have shown their potential as an anticancer therapy [136].

Acid ceramidase (ASAH1) has been detected to be overexpressed in melanomas, conferring resistance to chemotherapy. The involvement of ASAH1 in mitochondrial function and cellular autophagy in melanoma cells has been observed [137]. Furthermore, a recent study has shown that deletion of the ASAH1 gene blocks the induction of apoptosis mediated by doxorubicin [138]. These results may be due to the high adaptive capacity of melanoma cells. However, inhibition of ASAH1 with siRNA or pharmacologically with LCL521 in colorectal cancer cell lines (HT29, HCT116 and LIM1215) enhanced X-ray radiosensitivity [139]. Moreover, tamoxifen has shown its ability to inhibit ASAH1 in polyploid giant cancer cells by reducing their division [140]. Recently, the synthesis of $\mathrm{N}$-metallocenoylsphingosines has been described, demonstrating its cytotoxic capacity and inhibition of the cell cycle in cancer cells [141].

Alkaline ceramidase (ACER) has been described as being highly related to the growth, migration and invasion of tumor cells [142-144]. In this sense, incubation of HepG2 and Huh-7 human liver cancer cells with the ACER2 inhibitor, called D-erythro-MAPP (D-eMAPP), has been shown to reduce cell growth [142]. Structural analogues of ceramides have demonstrated their efficacy as selective ACER inhibitors, blocking cell growth and being suitable candidates for anticancer treatment $[145,146]$. More specifically, deoxysphingolipid analogs have recently been described as highly selective molecules and potent ACER3 inhibitors, with the ability to inhibit the cell cycle [147]. Of interest, the structure of ACER3 has recently been described, allowing structural and computational studies for the development of new specific inhibitors [148].

Neutral ceramidase is mostly expressed in the intestine and is highly related to the progression of colon cancer [149]. Studies with ASAH2 knockdown (ASAH2 ${ }^{-/}$) mice demonstrated that deletion of ASAH2 inhibited cell and tumor growth, both in vitro and in vivo, through the WNT/ $\beta$-catenin, ERK, GSK-3 $\beta$ and Akt pathways [150,151]. In addition, inhibition with a specific inhibitor, $\mathrm{C}_{6}$-urea-ceramide, obtained similar results $[150,151]$.

Adiponectin receptors (ADIPORs) are membrane proteins implicated in the control of glucose and lipid metabolism. Different studies have determined the incidence relationship 
of certain cancers with polymorphisms of the genes that code for ADIPORs [152-154]. Moreover, several studies have demonstrated the efficiency of ADIPORs agonists to induce cell death in cancer cells, such as (2-(4-Benzoylphenoxy)-N-[1-(phenylmethyl)-4-piperidinyl]acetamide) in cholangiocarcinoma [155], ADP355 in prostate cancer [156] or AdipoRon with pancreatic cancer cells [157]. Interestingly, it has recently been described that ADIPORs have ceramidase activity in their intracellular domain, increasing the levels of Cer, a pro-apoptotic metabolite [158].

\subsection{Sphingosine Kinase (SphK)/Sphingosine 1-Phosphate Phosphate (SPP)}

\subsubsection{Sphingosine Kinase (SphK)}

$\mathrm{S} 1 \mathrm{P}$ is one of the most studied bioactive sphingolipids in cell signaling and metabolism. It was first described as a pro-mitogenic and anti-apoptotic molecule [159]. The enzymes responsible for S1P generation are the sphingosine kinases (SphK), of which two different isoforms have been described, SphK1 and SphK2 [7,8]. In addition to its mitogenic, antiapoptotic and proinflammatory actions [4,160], S1P is implicated in cell migration, differentiation or tumorigenesis, and it is a key regulator of angiogenesis [161-171]. Besides being generated intracellularly, S1P is also present in the plasma at relatively high concentrations $(0.1 \mu \mathrm{M}$ to $1 \mu \mathrm{M})$ [172]. Interestingly, plasma S1P has been associated with its chemoattractant and pro-metastatic actions in cancer cells [162,171]. S1P is particularly increased in the plasma of patients with lung cancers [18] but has been implicated in the dissemination of tumors other than lung cancer, such as melanoma, human leukemia and hepatocellular carcinoma (HCC) [171,173-176].

A recent study in healthy volunteers revealed that S1P is also a major peripheral blood chemoattractant for bone marrow (BM)-residing hematopoietic stem/progenitor cells [177]. An interesting aspect of SphKs is their topology; whereas SphK1 is located in the cytosol, SphK2 is present in the nucleus. The different location of the two SphKs appears to be responsible for their different roles in cellular processes. Both SphK1 and SphK2 are related to inflammatory processes, cell proliferation and tumor spreading [178].

Overexpression of SphK2 has been related to cell growth arrest and apoptosis stimulation [179-181]. However, its overexpression was found in the nuclei of MCF7 human breast cancer cells [182] and was found to promote osteosarcoma cell growth [183].

Interestingly, in a clinical study with patients with glioblastoma, a correlation between SphK1 and poor survival was observed [184]. Moreover, selective inhibition of SphK1 or SphK2 with siRNA in U-1242 and U-87MG glioblastoma cell lines showed an inhibition of cell proliferation, with more potent action when SphK2 was silenced [184]. In addition, SphK2 has been implicated in chemotherapeutic drug doxorubicin-mediated apoptosis in HCT116 colon carcinoma cells, increasing its effect by down-regulation of SphK2 with specific siRNA [182]. More recently, it has been observed that a specific SphK2 inhibitor (ABC294640) increases the antitumor effect of tumor necrosis factor-related apoptosis inducing ligand (TRAIL) treatment in non-small cell lung cancer [185].

Another important feature of S1P biology has been the development of specific inhibitors of SphK1, as well as agonists and antagonists of S1P itself. These compounds have shown efficiency and effectiveness in the treatment of a variety of diseases, including liver fibrosis, multiple sclerosis or cancer. Specifically, fingolimod (FTY720) is an important S1P receptor antagonist used in the clinic [186-189]. This compound has been used to treat a variety of inflammatory diseases, including multiple sclerosis [190,191] or uveoretinitis [192], and can reduce liver and lung metastasis in rats [171]. However, due to its immunosuppressant properties, fingolimod might increase the risk for developing other types of cancer and might facilitate opportunistic infections that may have detrimental effects or be fatal for the organism [193]. In addition, down-regulation of SphK1 by specific siRNA or the specific inhibitor SK1-I (also referred to as BML-258) induces apoptosis and suppresses growth of human glioblastoma cells and xenografts by a process involving inhibition of protein kinase $\mathrm{B}(\mathrm{PKB}$, also known as Akt) and the activation of c-Jun N-terminal kinase (JNK) [194]. Another selective SphK1 inhibitor, N,N-Dimethyl-D-erythro-sphingosine (DMS), was shown to modulate cellular ceramide levels and induce apoptosis in the hu- 
man lung cancer cells [195]. In addition, it has been described how the co-treatment of two SphK1 inhibitors, FTY-720 and PF453, together with doxorubicin, inhibits the cell growth of breast cancer cells [196]. Moreover, in other recent work, it was observed that the Kirsten rat sarcoma viral oncogene homolog (K-Ras) produced an increase in S1P and Cer levels. By SphK1 inhibition with PF453 inhibitor, or by silencing its expression, a decrease in S1P levels was determined, whereas no change in Cer levels were observed, triggering the block of the cell cycle [197].

There is also evidence showing that cancer cells stimulate the release of S1P from neighboring cells to self-stimulate cell proliferation and migration. Of interest, extracellular S1P exerts its biological functions through interaction with five different G-protein coupled receptors, named S1P receptors 1 to 5 (S1PR1-5). For details on the biology of S1P receptors, the reader is referred to elegant reviews by A. Carter et al. [198], M. Maceyka et al. [170] or N.J. Pyne et al. [199].

\subsubsection{Sphingosine 1-Phosphate Phosphatase (SPP, also Known as SGPP)}

Sphingosine and S1P are readily interconvertible by the action of specific kinases and phosphatases (SPP1 and SPP2) [200] and, possibly, also by non-specific extracellular lipid phosphate phosphatases (LPPs) $[55,201]$. These phosphatases hydrolyze the phosphate group of S1P to produce sphingosine, which can then be converted to ceramide by CerS [202]. In animal models lacking expression of SPP1 and SPP2, developmental disorders in the epidermis and gastric tract have been observed [203,204], suggesting a relevant role of these enzymes in epithelial and skin integrity and development. In addition, mouse models with the deletion of exons 3 and 4 of the genes coding for SPP1 and SPP2 produced mouse neonates that died within a few days or adult mice that developed type 2 diabetes, respectively [205]. Furthermore, SPP1 expression was significantly lower in gastric tumor tissue than that in normal tissue, and treatment with specific SPP1 siRNA showed increased cell migration and invasion in gastric cancer [206]. Noteworthily, silencing of SPP1 in epidermal cells increased the chemoattractant effect of epidermal growth factor (EGF) [207], and overexpression of microRNA miR-27a reduced SPP1 levels [208], leading to a promotion of colorectal cancer. For details on the role of SphK and SPP in cancer biology, the reader is referred to elegant reviews by L.M. Obeid and coworkers $[209,210]$ and N. Pyne and coworkers [199,211].

\subsection{Ceramide Kinase (Cerk), Phosphatases and CERT}

C1P was first demonstrated to be mitogenic [212-216] and to inhibit apoptosis in a variety of cell types [217-221], thereby implicating CerK in the regulation of cell growth and survival. The role of CerK in cell growth and survival of normal and transformed cells has been widely addressed by different groups (reviewed in $[4,222])$. The mechanisms whereby C1P exerts its mitogenic or pro-survival actions include activation of different signaling pathways, such as mitogen-activated protein kinase kinase (MEK), extracellularly regulated kinases (ERKs) 1/2, phosphatidylinositol 3-kinase (PI3K)/Akt, mammalian target of rapamycin (mTOR), c-Jun N-terminal kinase (JNK) and protein kinase C- $\alpha[6,189,215,223]$, or stimulation of vascular endothelial cell growth factor (VEGF) secretion [216]. C1P-promoted cell survival involved direct inhibition of aSMase [224,225] or SPT [220], upregulation of inducible nitric oxide synthase (iNOS) expression [219] or activation of Akt [218]. CerK is particularly relevant in lung and breast cancer cell proliferation and dissemination [226,227]. Down-regulation of CerK expression using specific siRNA blocked progression of A549 human lung adenocarcinoma cells, reduced cancer cell proliferation and enhanced apoptosis in these cells [226]. Likewise, inhibition of CerK activity with the selective inhibitor NVP-231 blocked human epithelial lung cancer cell proliferation [228], whereas overexpression of CerK enhanced cell proliferation and protected against apoptosis. Furthermore, upregulation of CerK is profoundly important for the development of human breast cancer. Studies from patient biopsies revealed that increased CerK expression is associated with an elevated risk of tumor recurrence in women with breast cancer [229]. 
Another relevant aspect of Cerk biology is its implication in inflammatory responses. Initial studies by Chalfant and co-workers demonstrated the proinflammatory properties of C1P in different cell types (reviewed in [230-232]). It should be noted that chronic inflammation is closely associated with tumor development of different types of cancer. However, in normal lung cells, C1P seems to exert anti-inflammatory actions [233-235]. The dual actions of C1P in inflammation have been previously reviewed $[4,222,236]$.

Several drug-resistance cancer cell lines showed upregulated levels of CERT. Recently, the effectiveness of the inhibition of Cer transport to the Golgi apparatus by inhibition of CERT has been demonstrated as an anti-cancer treatment [237]. The HPA-12 inhibitor had already demonstrated its effectiveness as a CERT inhibitor, increasing Cer concentration and cell death [238]. Since then, several studies have described structurally similar inhibitors, effective in inhibiting CERT $[239,240]$. Recently, Nakao et al. synthesized and characterized a new CERT inhibitor, named (1S, 2R)-HPCB-5 [241]. Moreover, structural and affinity studies, followed for binding experiments of Cer to CERT, have been carried out on different drugs. This study has shown that drugs such as Lomitapide, Clevidipine, Fluralaner and Eltrombopag inhibit CERT in HeLa cells [242]. In addition, N,O-Dialkyl deoxynojirimycin derivatives have been described as CERT inhibitors in vitro [243].

Inhibitors and activators of enzymes involved in sphingosine and ceramide metabolism are summarized in Table 1.

Table 1. Enzyme inhibitors and activators that efficiently alter ceramide metabolism.

\begin{tabular}{|c|c|c|c|}
\hline $\begin{array}{l}\text { Targeted } \\
\text { Enzyme }\end{array}$ & Effector (Function) & Tissue/Cell Type & Ref. \\
\hline \multirow{6}{*}{ SPT } & $\begin{array}{l}\text { Myriocin } \\
\text { (inhibitor) }\end{array}$ & $\begin{array}{l}\text { B16F10 melanoma cells; } \\
\text { Human lung adenocarcinoma cell line } \\
\text { (HCC4006); Human glioblastoma cells } \\
\text { (U87MG) } \\
\text { Breast cancer cells }\end{array}$ & {$[19,61-63]$} \\
\hline & $\begin{array}{l}\text { Tetrahydropyrazolopyridine; } \\
\text { 3-phenylpiperidine } \\
\text { (inhibitors) }\end{array}$ & $\begin{array}{l}\text { PL-21 cells derived from an acute } \\
\text { promyelocytic leukemia; Human lung } \\
\text { adenocarcinoma cell line (HCC4006) }\end{array}$ & {$[27,64]$} \\
\hline & Fenretinide (activator) & Ovarian; Breast and neuroblastoma tumor cells & {$[65,66]$} \\
\hline & Taxol (activator) & Human breast cancer cells & [82] \\
\hline & Resveratrol (activator) & Metastatic breast cancer cells & [67] \\
\hline & Anti-androgens (activator) & Prostate cancer & [70] \\
\hline \multirow{5}{*}{ CerS } & $\begin{array}{l}\text { Anthracyclines, Vinblastine } \\
\text { (Activators) }\end{array}$ & Liver & {$[80,81]$} \\
\hline & Taxol (activator) & Human breast cancer cells & [82] \\
\hline & $\begin{array}{l}\text { Antifolate methotrexate } \\
\text { (indirect activator) }\end{array}$ & A549 lung adenocarcinoma cells & [83] \\
\hline & P053 (inhibitor) & HEK 293 cells & [77] \\
\hline & ST1058, ST1060, ST1072, ST1074 & HCT-106 and HeLa cells & [79] \\
\hline \multirow{6}{*}{ Des1 } & Resveratrol (inhibitor) & $\begin{array}{l}\text { Gastric cancer HGC27 cells; } \\
\text { T98G and U87MG glioblastoma cell lines }\end{array}$ & {$[88,91]$} \\
\hline & $\gamma$-tocotrienol, phenoxodiol, celecoxib (inhibitors) & T98G and U87MG glioblastoma cell lines & [88] \\
\hline & $\begin{array}{l}\text { Dideuterated analog of 3-keotsphinganine } \\
\text { (inhibitor) }\end{array}$ & HGC27, T98G and U87MG cancer cells & [92] \\
\hline & $\begin{array}{l}\text { Fenretinide combined } \\
\text { with Foscan (inhibitor) }\end{array}$ & $\begin{array}{l}\text { SCC19 human head and neck squamous cell } \\
\text { carcinoma }\end{array}$ & [93] \\
\hline & GT11 (inhibitor) & \multirow[b]{2}{*}{ Human U87MG glioma cell line } & \multirow[b]{2}{*}{ [89] } \\
\hline & $\begin{array}{l}\text { Tetrahydrocannabinol (THC) by indirect } \\
\text { mechanism inhibition }\end{array}$ & & \\
\hline
\end{tabular}


Table 1. Cont

\begin{tabular}{|c|c|c|c|}
\hline $\begin{array}{l}\text { Targeted } \\
\text { Enzyme }\end{array}$ & Effector (Function) & Tissue/Cell Type & Ref. \\
\hline \multirow{7}{*}{ SMase } & Gamma radiation (activator) & Liver & [36] \\
\hline & GW4869 (inhibitor) & Lung from human melanoma cells & [113] \\
\hline & siRNA (inhibitor) & Adenocarcinoma cell line A549 & [97] \\
\hline & Doxorubicin (activator) & Breast cancer cells & [96] \\
\hline & Resveratrol (activator) & K562 and HCT116 cell lines & [99] \\
\hline & Perphenazine and fluphenazine (inhibitor) & Xenografted tumor growth & [105] \\
\hline & ARC39 (inhibitor) & L929, HepG2 and B16F10 cell lines & [106] \\
\hline GCS & PDMP & HeLa cell line & [129] \\
\hline$\beta$-GCase & siRNA & Gastric cancer & [134] \\
\hline \multirow{7}{*}{ Ceramidase } & LCL521 (inhibitor) & \multirow{2}{*}{ HT29, HCT116 and LIM1215 cell lines } & \multirow{2}{*}{ [139] } \\
\hline & siRNA & & \\
\hline & Tamoxifen (inhibitor) & Polyploid giant cancer cells & {$[140,244]$} \\
\hline & N-metallocenoylsphingosine (inhibitor) & High-5 insect cells & [141] \\
\hline & D-erythro-MAPP (inhibitor) & Hepatocellular carcinoma cells & [142] \\
\hline & Deoxy-sphingolipids (inhibitor) & Several cancer cells & {$[145,147]$} \\
\hline & $\mathrm{C}_{6}$-urea-ceramide (inhibitor) & Colon cancer cells & {$[150,151]$} \\
\hline \multirow{3}{*}{ SMS } & D609 (inhibitor) & Hippocampal neurons and glioblastoma & {$[117,118]$} \\
\hline & SMS siRNA & \multirow{2}{*}{ Breast cancer } & {$[119,121]$} \\
\hline & $15 \mathrm{w}$ (inhibitor) & & [119] \\
\hline \multirow{8}{*}{ SphK1 } & SK1 siRNA & U-1242 and U-87MG glioblastoma cell lines & [184] \\
\hline & $\begin{array}{l}\text { SK1-I (BML-258) } \\
\quad \text { (inhibitor) }\end{array}$ & Human glioblastoma cells and xenografts & [194] \\
\hline & $\begin{array}{c}\text { FTY-720 } \\
\text { (Degradation inhibition) }\end{array}$ & $\begin{array}{l}\text { Lymphocytes, microglia, myeloma, leukaemia, } \\
\text { prostate, lung, liver, breast, colon, gastric, } \\
\text { bladder, renal glioma and ovarian cancers }\end{array}$ & {$[186,187,245-257]$} \\
\hline & SphK ${ }^{-/-}$mouse models & Murine melanoma cells & [173] \\
\hline & $\begin{array}{l}\mathrm{N}, \mathrm{N} \text {-Dimethyl-D-erythro-sphingosine (DMS) } \\
\text { (inhibitor) }\end{array}$ & Human lung cancer & [195] \\
\hline & FTY-720 and PF453 & Breast cancer cells & [196] \\
\hline & PF453 & MCF10A cell line & [197] \\
\hline & SK1-II & Liver cancer cells & [258] \\
\hline \multirow[t]{2}{*}{ SphK2 } & Sphk2 siRNA & $\begin{array}{l}\text { U-1242 and U-87MG glioblastoma cell lines } \\
\text { and HCT116 colon carcinoma cells }\end{array}$ & {$[182,184]$} \\
\hline & ABC294640 (inhibitor) & non-small cell lung cancer & [185] \\
\hline \multirow{2}{*}{ SPP } & miR95 and miR21(inhibition) & Lung cancer & {$[259,260]$} \\
\hline & miR-27a (inhibition) & Colorectal cancer & [208] \\
\hline \multirow[b]{2}{*}{ CerK } & siRNA & A549 human lung adenocarcinoma cells & [226] \\
\hline & NVP-231 (inhibitor) & $\begin{array}{l}\text { MCF-7 and NCI-H358 human lung cancer cell } \\
\text { lines }\end{array}$ & [228] \\
\hline \multirow{4}{*}{ CERT } & HPA-12 family (inhibitors) & Chinese hamster ovary cells, HeLa cells & [238-240] \\
\hline & (1S, 2R)-HPCB-5 & HeLa cells & [241] \\
\hline & $\begin{array}{c}\text { Lomitapide, Clevidipine, Fluralaner and } \\
\text { Eltrombopag (inhibitors) }\end{array}$ & HeLa cells & [242] \\
\hline & N,O-Dialkyl deoxynojirimycin & in vitro & [243] \\
\hline
\end{tabular}




\section{Concluding Remarks}

Regulation of sphingolipid metabolism enzymes is a major topic of study in cell biology and disease. Both intracellular and extracellular sphingolipid levels are tightly controlled to ensure proper cell and tissue homeostasis. Ceramides are tumor suppressors; distinct molecular species may be implicated in different cellular functions, and they likely reflect distinct pathophysiological states. The above discussions point to ceramide metabolism as a potential target for developing novel strategies to treat tumor promotion and dissemination. Additionally, it was found that the combined use of conventional drugs with effectors of ceramide metabolism would make it possible to improve the effectiveness of conventional therapies.

The synthesis of new inhibitors of sphingolipid metabolism has shown its effectiveness. It has been observed that, depending on the type of cancer, the expression of sphingolipid metabolism enzymes is altered. The study of these variations, as well as the discovery of new inhibitors, is of vital importance.

Author Contributions: Conceptualization, A.O.; writing-original draft preparation, A.G.-L., U.D.A. and A.O.; writing-review and editing, A.G.-L.; U.D.A.; M.A.-N.; A.C.; A.O. visualization, A.O.; supervision, A.O. All authors have read and agreed to the published version of the manuscript.

Funding: A.O. thanks Gobierno Vasco-Departamento de Educación for the post-doctoral grant from 2017-2019 (ref. number: POS_2016_1_0092). Moreover, M.A.-N. (IFI18/00008) is a recipient of iPFIS contract, and A.C. has a predoctoral scholarship from Xunta de Galicia (IN606A-2021/015).

Acknowledgments: A.O. thanks Gobierno Vasco-Departamento de Educación for the post-doctoral grant from 2017-2019 (ref. number: POS_2016_1_0092). M.A.-N. thanks Instituto Carlos III for the predoctoral scholarship. A.C. thanks Xunta de Galicia for the predoctoral scholarship. Figure 1 was made with BioRender.com software.

Conflicts of Interest: The authors declare no conflict of interest.

\section{References}

1. Hannun, Y.A.; Loomis, C.R.; Merrill, A.H., Jr.; Bell, R.M. Sphingosine Inhibition of Protein Kinase C Activity and of Phorbol Dibutyrate Binding in Vitro and in Human Platelets. J. Biol. Chem. 1986, 261, 12604-12609. [CrossRef]

2. Hannun, Y.A.; Obeid, L.M. Principles of Bioactive Lipid Signalling: Lessons from Sphingolipids. Nat. Rev. Mol. Cell Biol. 2008, 9 , 139-150. [CrossRef]

3. Gangoiti, P.; Camacho, L.; Arana, L.; Ouro, A.; Granado, M.H.; Brizuela, L.; Casas, J.; Fabrias, G.; Abad, J.L.; Delgado, A.; et al. Control of Metabolism and Signaling of Simple Bioactive Sphingolipids: Implications in Disease. Prog. Lipid Res. 2010, 49, 316-334. [CrossRef]

4. Gomez-Larrauri, A.; Presa, N.; Dominguez-Herrera, A.; Ouro, A.; Trueba, M.; Gomez-Munoz, A. Role of Bioactive Sphingolipids in Physiology and Pathology. Essays Biochem. 2020, 64, 579-589. [CrossRef]

5. Arana, L.; Gangoiti, P.; Ouro, A.; Trueba, M.; Gomez-Munoz, A.; Gómez-Muñoz, A. Ceramide and Ceramide 1-Phosphate in Health and Disease. Lipids Health Dis. 2010, 9, 15. [CrossRef]

6. Gangoiti, P.; Granado, M.H.; Wei, S.; Kong, J.Y.; Steinbrecher, U.P.; Gómez-muñoz, A. Ceramide 1-Phosphate Stimulates Macrophage Proliferation through Activation of the PI3-Kinase/PKB, JNK and ERK1/2 Pathways. Cell. Signal. 2008, 20, 726-736. [CrossRef]

7. Maceyka, M.; Payne, S.G.; Milstien, S.; Spiegel, S. Sphingosine Kinase, Sphingosine-1-Phosphate, and Apoptosis. Biochim. Biophys. Acta 2002, 1585, 193-201. [CrossRef]

8. Taha, T.A.; Hannun, Y.A.; Obeid, L.M. Sphingosine Kinase: Biochemical and Cellular Regulation and Role in Disease. J. Biochem. Mol. Biol. 2006, 39, 113-131. [CrossRef]

9. Simanshu, D.K.; Kamlekar, R.K.; Wijesinghe, D.S.; Zou, X.; Zhai, X.; Mishra, S.K.; Molotkovsky, J.G.; Malinina, L.; Hinchcliffe, E.H.; Chalfant, C.E.; et al. Non-Vesicular Trafficking by a Ceramide-1-Phosphate Transfer Protein Regulates Eicosanoids. Nature 2013, 500, 463-467. [CrossRef]

10. Liang, H.; Yao, N.; Song, J.T.; Luo, S.; Lu, H.; Greenberg, J.T. Ceramides Modulate Programmed Cell Death in Plants. Genes Dev. 2003, 17, 2636-2641. [CrossRef]

11. Boath, A.; Graf, C.; Lidome, E.; Ullrich, T.; Nussbaumer, P.; Bornancin, F. Regulation and Traffic of Ceramide 1-Phosphate Produced by Ceramide Kinase: Comparative Analysis to Glucosylceramide and Sphingomyelin. J. Biol. Chem. 2008, 283, 8517-8526. [CrossRef]

12. Guan, X.L.; Mäser, P. Comparative Sphingolipidomics of Disease-Causing Trypanosomatids Reveal Unique Lifecycle- and Taxonomy-Specific Lipid Chemistries. Sci. Rep. 2017, 7, 1-13. [CrossRef] [PubMed] 
13. Mielke, M.M.; Haughey, N.J.; Bandaru, V.V.R.; Zetterberg, H.; Blennow, K.; Andreasson, U.; Johnson, S.C.; Gleason, C.E.; Blazel, H.M.; Puglielli, L.; et al. Cerebrospinal Fluid Sphingolipids, $\beta$-Amyloid, and Tau in Adults at Risk for Alzheimer's Disease. Neurobiol. Aging 2014, 35, 2486-2494. [CrossRef]

14. van Kruining, D.; Luo, Q.; van Echten-Deckert, G.; Mielke, M.M.; Bowman, A.; Ellis, S.; Oliveira, T.G.; Martinez-Martinez, P. Sphingolipids as Prognostic Biomarkers of Neurodegeneration, Neuroinflammation, and Psychiatric Diseases and Their Emerging Role in Lipidomic Investigation Methods. Adv. Drug Deliv. Rev. 2020, 159, 232-244. [CrossRef]

15. Griese, M.; Bonella, F.; Costabel, U.; de Blic, J.; Tran, N.-B.; Liebisch, G. Quantitative Lipidomics in Pulmonary Alveolar Proteinosis. Am. J. Respir. Crit. Care Med. 2019, 200, 881-887. [CrossRef]

16. Kurek, K.; Mikłosz, A.; Łukaszuk, B.; Chabowski, A.; Górski, J.; Zendzian-Piotrowska, M. Inhibition of Ceramide de Novo Synthesis Ameliorates Diet Induced Skeletal Muscles Insulin Resistance. J. Diabetes Res. 2015, 2015. [CrossRef]

17. Li, C.; Zhou, J.; Wang, A.; Li, N.; Chen, B.; Lei, M. Inhibition of Ceramide Synthesis Reverses Endothelial Dysfunction and Atherosclerosis in Streptozotocin-Induced Diabetic Rats. Diabetes Res. Clin. Pract. 2011, 93, 77-85. [CrossRef]

18. Alberg, A.J.; Armeson, K.; Pierce, J.S.; Bielawski, J.; Bielawska, A.; Visvanathan, K.; Hill, E.G.; Ogretmen, B. Plasma Sphingolipids and Lung Cancer: A Population-Based, Nested Case-Control Study. Cancer Epidemiol. Biomark. Prev. 2013, 22, $1374-1382$. [CrossRef]

19. Ogretmen, B. Sphingolipid Metabolism in Cancer Signalling and Therapy. Nat. Rev. Cancer 2018, 18, 33-50. [CrossRef]

20. Custodia, A.; Aramburu-Núñez, M.; Correa-Paz, C.; Posado-Fernández, A.; Gómez-Larrauri, A.; Castillo, J.; Gómez-Muñoz, A.; Sobrino, T.; Ouro, A. Ceramide Metabolism and Parkinson's Disease-Therapeutic Targets. Biomolecules 2021, 11, 945. [CrossRef]

21. Sheridan, M.; Ogretmen, B. The Role of Ceramide Metabolism and Signaling in the Regulation of Mitophagy and Cancer Therapy. Cancers 2021, 13, 2475. [CrossRef]

22. Wilhelm, R.; Eckes, T.; Imre, G.; Kippenberger, S.; Meissner, M.; Thomas, D.; Trautmann, S.; Merlio, J.P.; Chevret, E.; Kaufmann, R.; et al. C6 Ceramide (D18: 1/6: 0) as a Novel Treatment of Cutaneous T Cell Lymphoma. Cancers 2021, 13, 270. [CrossRef]

23. Xu, Y.; Pan, J.; Lin, Y.; Wu, Y.; Li, H.; Chen, Y. C6-Ceramide Induces Apoptosis in Lung Non-Small Cell Lung Cancer and Suppresses Brain Metastasis by Downregulating the PI3K/AKT/MTOR Signaling Pathway. Res. Sq. 2021. [CrossRef]

24. Zhang, Y.; Wang, H.; Chen, T.; Wang, H.; Liang, X.; Zhang, Y.; Duan, J.; Qian, S.; Qiao, K.; Zhang, L.; et al. C24-Ceramide Drives Gallbladder Cancer Progression Through Directly Targeting Phosphatidylinositol 5-Phosphate 4-Kinase Type-2 Gamma to Facilitate Mammalian Target of Rapamycin Signaling Activation. Hepatology 2021, 73, 692-712. [CrossRef]

25. Watters, R.J.; Kester, M.; Tran, M.A.; Loughran, T.P.; Liu, X. Development and Use of Ceramide Nanoliposomes in Cancer. Methods Enzymol. 2012, 508, 89-108. [CrossRef] [PubMed]

26. Wang, Y.; Niu, Y.; Zhang, Z.; Gable, K.; Gupta, S.D.; Somashekarappa, N.; Han, G.; Zhao, H.; Myasnikov, A.G.; Kalathur, R.C.; et al. Structural Insights into the Regulation of Human Serine Palmitoyltransferase Complexes. Nat. Struct. Mol. Biol. 2021, 28, $240-248$. [CrossRef]

27. Kojima, T.; Asano, Y.; Kurasawa, O.; Hirata, Y.; Iwamura, N.; Wong, T.T.; Saito, B.; Tanaka, Y.; Arai, R.; Yonemori, K.; et al. Discovery of Novel Serine Palmitoyltransferase Inhibitors as Cancer Therapeutic Agents. Bioorg. Med. Chem. 2018, 26, $2452-2465$. [CrossRef]

28. Genin, M.J.; Gonzalez Valcarcel, I.C.; Holloway, W.G.; Lamar, J.; Mosior, M.; Hawkins, E.; Estridge, T.; Weidner, J.; Seng, T.; Yurek, D.; et al. Imidazopyridine and Pyrazolopiperidine Derivatives as Novel Inhibitors of Serine Palmitoyl Transferase. J. Med. Chem. 2016, 59, 5904-5910. [CrossRef]

29. Pant, D.C.; Dorboz, I.; Schluter, A.; Fourcade, S.; Launay, N.; Joya, J.; Aguilera-Albesa, S.; Yoldi, M.E.; Casasnovas, C.; Willis, M.J.; et al. Loss of the Sphingolipid Desaturase DEGS1 Causes Hypomyelinating Leukodystrophy. J. Clin. Investig. 2019, 129, 1240-1256. [CrossRef] [PubMed]

30. Karsai, G.; Kraft, F.; Haag, N.; Christoph Korenke, G.; Hänisch, B.; Othman, A.; Suriyanarayanan, S.; Steiner, R.; Knopp, C.; Mull, M.; et al. DEGS1-Associated Aberrant Sphingolipid Metabolism Impairs Nervous System Function in Humans. J. Clin. Investig. 2019, 129, 1229-1239. [CrossRef] [PubMed]

31. Ohi, K.; Ursini, G.; Li, M.; Shin, J.H.; Ye, T.; Chen, Q.; Tao, R.; Kleinman, J.E.; Hyde, T.M.; Hashimoto, R.; et al. DEGS2 Polymorphism Associated with Cognition in Schizophrenia Is Associated with Gene Expression in Brain. Transl. Psychiatry 2015, 5, 550. [CrossRef] [PubMed]

32. Casasampere, M.; Ordoñez, Y.F.; Pou, A.; Casas, J. Inhibitors of Dihydroceramide Desaturase 1: Therapeutic Agents and Pharmacological Tools to Decipher the Role of Dihydroceramides in Cell Biology. Chem. Phys. Lipids 2016, 197, 33-44. [CrossRef] [PubMed]

33. Chaurasia, B.; Tippetts, T.S.; Monibas, R.M.; Liu, J.; Li, Y.; Wang, L.L.; Wilkerson, J.L.; Rufus Sweeney, C.; Pereira, R.F.; Sumida, D.H.; et al. Targeting a Ceramide Double Bond Improves Insulin Resistance and Hepatic Steatosis. Science 2019, 365, $386-392$. [CrossRef] [PubMed]

34. Jojima, K.; Edagawa, M.; Sawai, M.; Ohno, Y.; Kihara, A. Biosynthesis of the Anti-Lipid-Microdomain Sphingoid Base 4,14Sphingadiene by the Ceramide Desaturase FADS3. FASEB J. 2020, 34, 3318-3335. [CrossRef] [PubMed]

35. Karsai, G.; Lone, M.; Kutalik, Z.; Brenna, J.T.; Li, H.; Pan, D.; von Eckardstein, A.; Hornemann, T. FADS3 Is a $\Delta 14 Z$ Sphingoid Base Desaturase That Contributes to Gender Differences in the Human Plasma Sphingolipidome. J. Biol. Chem. 2020, 295, 1889-1897. [CrossRef] 
36. Cataldi, S.; Borrelli, A.; Ceccarini, M.R.; Nakashidze, I.; Codini, M.; Belov, O.; Ivanov, A.; Krasavin, E.; Ferri, I.; Conte, C.; et al. Acid and Neutral Sphingomyelinase Behavior in Radiation-Induced Liver Pyroptosis and in the Protective/Preventive Role of RMnSOD. Int. J. Mol. Sci. 2020, 21, 3281. [CrossRef]

37. Goni, F.M.; Alonso, A. Sphingomyelinases: Enzymology and Membrane Activity. FEBS Lett. 2002, 531, 38-46. [CrossRef]

38. Jenkins, R.W.; Canals, D.; Idkowiak-Baldys, J.; Simbari, F.; Roddy, P.; Perry, D.M.; Kitatani, K.; Luberto, C.; Hannun, Y.A. Regulated Secretion of Acid Sphingomyelinase: Implications for Selectivity of Ceramide Formation. J. Biol. Chem. 2010, 285, 35706-35718. [CrossRef]

39. Becker, K.A.; Riethmuller, J.; Luth, A.; Doring, G.; Kleuser, B.; Gulbins, E. Acid Sphingomyelinase Inhibitors Normalize Pulmonary Ceramide and Inflammation in Cystic Fibrosis. Am. J. Respir. Cell Mol. Biol. 2010, 42, 716-724. [CrossRef] [PubMed]

40. Gomez-Muñoz, A.; Gangoiti, P.; Arana, L.; Ouro, A.; Rivera, I.G.; Ordoñez, M.; Trueba, M. New Insights on the Role of Ceramide 1-Phosphate in Inflammation. Biochim. Biophys. Acta Mol. Cell Biol. Lipids 2013, 1831, 1060-1066. [CrossRef]

41. Morad, S.A.F.; Cabot, M.C. Ceramide-Orchestrated Signalling in Cancer Cells. Nat. Rev. Cancer 2012, 13, 51-65. [CrossRef]

42. Kitatani, K.; Idkowiak-Baldys, J.; Hannun, Y.A. The Sphingolipid Salvage Pathway in Ceramide Metabolism and Signaling. Cell. Signal. 2008, 20, 1010-1018. [CrossRef] [PubMed]

43. Levy, M.; Futerman, A.H. Mammalian Ceramide Synthases. IUBMB Life 2010, 62, 347-356. [CrossRef] [PubMed]

44. Verlekar, D.; Wei, S.J.; Cho, H.; Yang, S.; Kang, M.H. Ceramide Synthase-6 Confers Resistance to Chemotherapy by Binding to CD95/Fas in T-Cell Acute Lymphoblastic Leukemia. Cell Death Dis. 2018, 9, 1-14. [CrossRef]

45. Park, J.W.; Park, W.J.; Futerman, A.H. Ceramide Synthases as Potential Targets for Therapeutic Intervention in Human Diseases. Biochim. Biophys. Acta Mol. Cell Biol. Lipids 2014, 1841, 671-681. [CrossRef]

46. Kim, J.L.; Mestre, B.; Shin, S.-H.; Futerman, A.H. Ceramide Synthases: Reflections on the Impact of Dr. Lina M. Obeid. Cell. Signal. 2021, 82, 109958. [CrossRef] [PubMed]

47. Raichur, S.; Wang, S.T.; Chan, P.W.; Li, Y.; Ching, J.; Chaurasia, B.; Dogra, S.; Öhman, M.K.; Takeda, K.; Sugii, S.; et al. CerS2 Haploinsufficiency Inhibits $\beta$-Oxidation and Confers Susceptibility to Diet-Induced Steatohepatitis and Insulin Resistance. Cell Metab. 2014, 20, 687-695. [CrossRef] [PubMed]

48. Turpin, S.M.; Nicholls, H.T.; Willmes, D.M.; Mourier, A.; Brodesser, S.; Wunderlich, C.M.; Mauer, J.; Xu, E.; Hammerschmidt, P.; Brönneke, H.S.; et al. Obesity-Induced CerS6-Dependent C16:0 Ceramide Production Promotes Weight Gain and Glucose Intolerance. Cell Metab. 2014, 20, 678-686. [CrossRef]

49. Coant, N.; Hannun, Y.A. Neutral Ceramidase: Advances in Mechanisms, Cell Regulation, and Roles in Cancer. Adv. Biol. Regul. 2019, 71, 141-146. [CrossRef] [PubMed]

50. Romiti, E.; Meacci, E.; Tani, M.; Nuti, F.; Farnararo, M.; Ito, M.; Bruni, P. Neutral/Alkaline and Acid Ceramidase Activities Are Actively Released by Murine Endothelial Cells. Biochem. Biophys. Res. Commun. 2000, 275, 746-751. [CrossRef]

51. Gebai, A.; Gorelik, A.; Li, Z.; Illes, K.; Nagar, B. Structural Basis for the Activation of Acid Ceramidase. Nat. Commun. 2018, 9 , 1-11. [CrossRef] [PubMed]

52. Xu, R.; Antwi Boasiako, P.; Mao, C. Alkaline Ceramidase Family: The First Two Decades. Cell. Signal. 2021, 78, 109860. [CrossRef]

53. Saba, J.D. Fifty Years of Lyase and a Moment of Truth: Sphingosine Phosphate Lyase from Discovery to Disease. J. Lipid Res. 2019, 60, 456-463. [CrossRef]

54. Boudker, O.; Futerman, A.H. Detection and Characterization of Ceramide-1-Phosphate Phosphatase Activity in Rat Liver Plasma Membrane. J. Biol. Chem. 1993, 268, 22150-22155. [CrossRef]

55. Waggoner, D.W.; Gomez-Munoz, A.; Dewald, J.; Brindley, D.N. Phosphatidate Phosphohydrolase Catalyzes the Hydrolysis of Ceramide 1-Phosphate, Lysophosphatidate, and Sphingosine 1-Phosphate. J. Biol. Chem. 1996, 271, 16506-16509. [CrossRef]

56. Campbell, K.N.; Tumlin, J.A. Protecting Podocytes: A Key Target for Therapy of Focal Segmental Glomerulosclerosis. Am. J. Nephrol. 2018, 47, 14-29. [CrossRef]

57. Mallela, S.K.; Mitrofanova, A.; Merscher, S.; Fornoni, A. Regulation of the Amount of Ceramide-1-Phosphate Synthesized in Differentiated Human Podocytes. Biochim. Et Biophys. Acta Mol. Cell Biol. Lipids 2019, 1864, 158517. [CrossRef]

58. Glaros, E.N.; Kim, W.S.; Wu, B.J.; Suarna, C.; Quinn, C.M.; Rye, K.A.; Stocker, R.; Jessup, W.; Garner, B. Inhibition of Atherosclerosis by the Serine Palmitoyl Transferase Inhibitor Myriocin Is Associated with Reduced Plasma Glycosphingolipid Concentration. Biochem. Pharmacol. 2007, 73, 1340-1346. [CrossRef]

59. Kluepfel, D.; Bagli, J.; Baker, H.; Charest, M.P.; Kudelski, A.; Sehgal, S.N.; Vézina, C. Myriocin, a New Antifungal Antibiotic from Myriococcum Albomyces. J. Antibiot. 1972, 25, 109-115. [CrossRef]

60. Riley, R.T.; Norred, W.P.; Wang, E.; Merrill, A.H. Alteration in Sphingolipid Metabolism: Bioassays for Fumonisin- and ISP-I-like Activity in Tissues, Cells and Other Matrices. Nat. Toxins 1999, 7, 407-414. [CrossRef]

61. Lee, Y.S.; Choi, K.M.; Choi, M.H.; Ji, S.Y.; Lee, S.; Sin, D.M.; Oh, K.W.; Lee, Y.M.; Hong, J.T.; Yun, Y.P.; et al. Serine Palmitoyltransferase Inhibitor Myriocin Induces Growth Inhibition of B16F10 Melanoma Cells through G2/M Phase Arrest. Cell Prolif. 2011, 44, 320-329. [CrossRef] [PubMed]

62. Sano, O.; Kazetani, K.; Adachi, R.; Kurasawa, O.; Kawamoto, T.; Iwata, H. Using a Biologically Annotated Library to Analyze the Anticancer Mechanism of Serine Palmitoyl Transferase (SPT) Inhibitors. FEBS Open Bio 2017, 7, 495-503. [CrossRef] [PubMed]

63. Bernhart, E.; Damm, S.; Wintersperger, A.; Nusshold, C.; Brunner, A.M.; Plastira, I.; Rechberger, G.; Reicher, H.; Wadsack, C.; Zimmer, A.; et al. Interference with Distinct Steps of Sphingolipid Synthesis and Signaling Attenuates Proliferation of U87MG Glioma Cells. Biochem. Pharmacol. 2015, 96, 119-130. [CrossRef] 
64. Yaguchi, M.; Shibata, S.; Satomi, Y.; Hirayama, M.; Adachi, R.; Asano, Y.; Kojima, T.; Hirata, Y.; Mizutani, A.; Kiba, A.; et al. Antitumor Activity of a Novel and Orally Available Inhibitor of Serine Palmitoyltransferase. Biochem. Biophys. Res. Commun. 2017, 484, 493-500. [CrossRef]

65. Maurer, B.J.; Metelitsa, L.S.; Seeger, R.C.; Cabot, M.C.; Patrick Reynolds, C. Increase of Ceramide and Induction of Mixed Apoptosis/Necrosis by N-(4- Hydroxyphenyl)-Retinamide in Neuroblastoma Cell Lines. J. Natl. Cancer Inst. 1999, 91, 1138-1146. [CrossRef]

66. Villani, M.G.; Appierto, V.; Cavadini, E.; Bettiga, A.; Prinetti, A.; Clagett-Dame, M.; Curley, R.W.; Formelli, F. 4-Oxo-Fenretinide, a Recently Identified Fenretinide Metabolite, Induces Marked G2-M Cell Cycle Arrest and Apoptosis in Fenretinide-Sensitive and Fenretinide-Resistant Cell Lines. Cancer Res. 2006, 66, 3238-3247. [CrossRef] [PubMed]

67. Scarlatti, F.; Sala, G.; Somenzi, G.; Signorelli, P.; Sacchi, N.; Ghidoni, R. Resveratrol Induces Growth Inhibition and Apoptosis in Metastatic Breast Cancer Cells via de Novo Ceramide Signaling. FASEB J. 2003, 17, 2339-2341. [CrossRef]

68. Hornemann, T.; Penno, A.; Rütti, M.F.; Ernst, D.; Kivrak-Pfiffner, F.; Rohrer, L.; von Eckardstein, A. The SPTLC3 Subunit of Serine Palmitoyltransferase Generates Short Chain Sphingoid Bases. J. Biol. Chem. 2009, 284, 26322-26330. [CrossRef]

69. Lone, M.A.; Hülsmeier, A.J.; Saied, E.M.; Karsai, G.; Arenz, C.; von Eckardstein, A.; Hornemann, T. Subunit Composition of the Mammalian Serine-Palmitoyltransferase Defines the Spectrum of Straight and Methyl-Branched Long-Chain Bases. Proc. Natl. Acad. Sci. USA 2020, 117, 15591-15598. [CrossRef]

70. Costa-Pinheiro, P.; Heher, A.; Raymond, M.H.; Jividen, K.; Shaw, J.J.; Paschal, B.M.; Walker, S.J.; Fox, T.E.; Kester, M. Role of SPTSSB-Regulated de Novo Sphingolipid Synthesis in Prostate Cancer Depends on Androgen Receptor Signaling. IScience 2020, 23, 101855. [CrossRef]

71. Gable, K.; Slife, H.; Bacikova, D.; Monaghan, E.; Dunn, T.M. Tsc3p Is an 80-Amino Acid Protein Associated with Serine Palmitoyltransferase and Required for Optimal Enzyme Activity. J. Biol. Chem. 2000, 275, 7597-7603. [CrossRef] [PubMed]

72. Ren, J.; Saied, E.M.; Zhong, A.; Snider, J.; Ruiz, C.; Arenz, C.; Obeid, L.M.; Girnun, G.D.; Hannun, Y.A. Tsc3 Regulates SPT Amino Acid Choice in Saccharomyces Cerevisiae by Promoting Alanine in the Sphingolipid Pathway. J. Lipid Res. 2018, 59, 2126-2139. [CrossRef]

73. Wang, Z.; Wen, L.; Zhu, F.; Wang, Y.; Xie, Q.; Chen, Z.; Li, Y. Overexpression of Ceramide Synthase 1 Increases C18-Ceramide and Leads to Lethal Autophagy in Human Glioma. Oncotarget 2017, 8, 104022-104036. [CrossRef]

74. Moro, K.; Nagahashi, M.; Gabriel, E.; Takabe, K.; Wakai, T. Clinical Application of Ceramide in Cancer Treatment. Breast Cancer 2019, 26, 407-415. [CrossRef]

75. Xia, Q.S.; Lu, F.E.; Wu, F.; Huang, Z.Y.; Dong, H.; Xu, L.J.; Gong, J. New Role for Ceramide in Hypoxia and Insulin Resistance. World J. Gastroenterol. 2020, 26, 2177-2186. [CrossRef]

76. Crivelli, S.M.; Luo, Q.; Stevens, J.A.A.; Giovagnoni, C.; van Kruining, D.; Bode, G.; den Hoedt, S.; Hobo, B.; Scheithauer, A.-L.; Walter, J.; et al. CERTL Reduces C16 Ceramide, Amyloid- $\beta$ Levels, and Inflammation in a Model of Alzheimer's Disease. Alzheimer's Res. Ther. 2021, 13, 45. [CrossRef]

77. Turner, N.; Lim, X.Y.; Toop, H.D.; Osborne, B.; Brandon, A.E.; Taylor, E.N.; Fiveash, C.E.; Govindaraju, H.; Teo, J.D.; McEwen, H.P.; et al. A Selective Inhibitor of Ceramide Synthase 1 Reveals a Novel Role in Fat Metabolism. Nat. Commun. 2018, 9, 1-14. [CrossRef]

78. Hartmann, D.; Lucks, J.; Fuchs, S.; Schiffmann, S.; Schreiber, Y.; Ferreirós, N.; Merkens, J.; Marschalek, R.; Geisslinger, G.; Grösch, S. Long Chain Ceramides and Very Long Chain Ceramides Have Opposite Effects on Human Breast and Colon Cancer Cell Growth. Int. J. Biochem. Cell Biol. 2012, 44, 620-628. [CrossRef] [PubMed]

79. Schiffmann, S.; Hartmann, D.; Fuchs, S.; Birod, K.; Ferreirs, N.; Schreiber, Y.; Zivkovic, A.; Geisslinger, G.; Grösch, S.; Stark, H. Inhibitors of Specific Ceramide Synthases. Biochimie 2012, 94, 558-565. [CrossRef]

80. Bose, R.; Verheij, M.; Haimovitz-friedman, A.; Scotto, K.; Fuks, Z.; Kolesnick, R. Ceramide Synthase Mediates DaunorubicinLnduced Apoptosis: An Alternative Mechanism for Generating Death Signals. Cell 1995, 82, 405-414. [CrossRef]

81. Cabot, M.C.; Han, T.; Giuliano, A.E. The Multidrug Resistance Modulator SDZ PSC 833 Is a Potent Activator of Cellular Ceramide Formation. FEBS Lett. 1998, 431, 185-188. [CrossRef]

82. Charles, A.G.; Han, T.Y.; Liu, Y.Y.; Hansen, N.; Giuliano, A.E.; Cabot, M.C. Taxol-Induced Ceramide Generation and Apoptosis in Human Breast Cancer Cells. Cancer Chemother. Pharmacol. 2001, 47, 444-450. [CrossRef] [PubMed]

83. Fekry, B.; Esmaeilniakooshkghazi, A.; Krupenko, S.A.; Krupenko, N.I. Ceramide Synthase 6 Is a Novel Target of Methotrexate Mediating Its Antiproliferative Effect in a P53-Dependent Manner. PLoS ONE 2016, 11, e0146618. [CrossRef] [PubMed]

84. Lu, P.; White-Gilbertson, S.; Beeson, G.; Beeson, C.; Ogretmen, B.; Norris, J.; Voelkel-Johnson, C. Ceramide Synthase 6 Maximizes P53 Function to Prevent Progeny Formation from Polyploid Giant Cancer Cells. Cancers 2021, 13, 2212. [CrossRef]

85. Boppana, N.B.; Kodiha, M.; Stochaj, U.; Lin, H.S.; Haimovitz-Friedman, A.; Bielawska, A.; Bielawski, J.; Divine, G.W.; Boyd, J.A.; Korbelik, M.; et al. Ceramide Synthase Inhibitor Fumonisin B1 Inhibits Apoptotic Cell Death in SCC17B Human Head and Neck Squamous Carcinoma Cells after Pc4 Photosensitization. Photochem. Photobiol. Sci. 2014, 13, 1621-1627. [CrossRef]

86. Holland, W.L.; Brozinick, J.T.; Wang, L.P.; Hawkins, E.D.; Sargent, K.M.; Liu, Y.; Narra, K.; Hoehn, K.L.; Knotts, T.A.; Siesky, A.; et al. Inhibition of Ceramide Synthesis Ameliorates Glucocorticoid-, Saturated-Fat-, and Obesity-Induced Insulin Resistance. Cell Metab. 2007, 5, 167-179. [CrossRef] 
87. Kraveka, J.M.; Li, L.; Szulc, Z.M.; Bielawski, J.; Ogretmen, B.; Hannun, Y.A.; Obeid, L.M.; Bielawska, A. Involvement of Dihydroceramide Desaturase in Cell Cycle Progression in Human Neuroblastoma Cells. J. Biol. Chem. 2007, 282, 16718-16728. [CrossRef]

88. Casasampere, M.; Ordóñez, Y.F.; Casas, J.; Fabrias, G. Dihydroceramide Desaturase Inhibitors Induce Autophagy via Dihydroceramide-Dependent and Independent Mechanisms. Biochim. Biophys. Acta Gen. Subj. 2017, 1861, 264-275. [CrossRef]

89. Hernández-Tiedra, S.; Fabriàs, G.; Dávila, D.; Salanueva, Í.J.; Casas, J.; Montes, L.R.; Antón, Z.; García-Taboada, E.; Salazar-Roa, M.; Lorente, M.; et al. Dihydroceramide Accumulation Mediates Cytotoxic Autophagy of Cancer Cells via Autolysosome Destabilization. Autophagy 2016, 12, 2213-2229. [CrossRef]

90. Missiroli, S.; Bonora, M.; Patergnani, S.; Poletti, F.; Perrone, M.; Gafà, R.; Magri, E.; Raimondi, A.; Lanza, G.; Tacchetti, C.; et al. PML at Mitochondria-Associated Membranes Is Critical for the Repression of Autophagy and Cancer Development. Cell Rep. 2016, 16, 2415-2427. [CrossRef]

91. Signorelli, P.; Munoz-Olaya, J.M.; Gagliostro, V.; Casas, J.; Ghidoni, R.; Fabriàs, G. Dihydroceramide Intracellular Increase in Response to Resveratrol Treatment Mediates Autophagy in Gastric Cancer Cells. Cancer Lett. 2009, 282, 238-243. [CrossRef]

92. Ordóñez, Y.F.; González, J.; Bedia, C.; Casas, J.; Abad, J.L.; Delgado, A.; Fabrias, G. 3-Ketosphinganine Provokes the Accumulation of Dihydroshingolipids and Induces Autophagy in Cancer Cells. Mol. Biosyst. 2016, 12, 1166-1173. [CrossRef] [PubMed]

93. Boppana, N.B.; Delor, J.S.; van Buren, E.; Bielawska, A.; Bielawski, J.; Pierce, J.S.; Korbelik, M.; Separovic, D. Enhanced Apoptotic Cancer Cell Killing after Foscan Photodynamic Therapy Combined with Fenretinide via de Novo Sphingolipid Biosynthesis Pathway. J. Photochem. Photobiol. B Biol. 2016, 159, 191-195. [CrossRef]

94. Malhi, H.; Guicciardi, M.E.; Gores, G.J. Hepatocyte Death: A Clear and Present Danger. Physiol. Rev. 2010, 90, 1165-1194. [CrossRef] [PubMed]

95. Clarke, C.J.; Cloessner, E.A.; Roddy, P.L.; Hannun, Y.A. Neutral Sphingomyelinase 2 (NSMase 2) Isthe Primary Neutral Sphingomyelinase Isoform Activated by Tumour Necrosis Factor- $\alpha$ in MCF-7 Cells. Biochem. J. 2011, 435, 381-390. [CrossRef]

96. Shamseddine, A.; Clarke, C.; Carroll, B.; Airola, M.V.; Mohammed, S.; Rella, A.; Obeid, L.; Hannun, Y. P53-Dependent Upregulation of Neutral Sphingomyelinase-2: Role in Doxorubicin-Induced Growth Arrest. Cell Death Dis. 2015, 6, e1947. [CrossRef]

97. Kachler, K.; Bailer, M.; Heim, L.; Schumacher, F.; Reichel, M.; Holzinger, C.D.; Trump, S.; Mittler, S.; Monti, J.; Trufa, D.I.; et al. Enhanced Acid Sphingomyelinase Activity Drives Immune Evasion and Tumor Growth in Non-Small Cell Lung Carcinoma. Cancer Res. 2017, 77, 5963-5976. [CrossRef]

98. Carpinteiro, A.; Becker, K.A.; Japtok, L.; Hessler, G.; Keitsch, S.; Požgajovà, M.; Schmid, K.W.; Adams, C.; Müller, S.; Kleuser, B.; et al. Regulation of Hematogenous Tumor Metastasis by Acid Sphingomyelinase. EMBO Mol. Med. 2015, 7, 714-734. [CrossRef]

99. Mizutani, N.; Omori, Y.; Kawamoto, Y.; Sobue, S.; Ichihara, M.; Suzuki, M.; Kyogashima, M.; Nakamura, M.; Tamiya-Koizumi, K.; Nozawa, Y.; et al. Resveratrol-Induced Transcriptional up-Regulation of ASMase (SMPD1) of Human Leukemia and Cancer Cells. Biochem. Biophys. Res. Commun. 2016, 470, 851-856. [CrossRef]

100. Kornhuber, J.; Tripal, P.; Reichel, M.; Mühle, C.; Rhein, C.; Muehlbacher, M.; Groemer, T.W.; Gulbins, E. Functional Inhibitors of Acid Sphingomyelinase (FIASMAS): A Novel Pharmacological Group of Drugs with Broad Clinical Applications. Cell. Physiol. Biochem. 2010, 26, 9-20. [CrossRef]

101. Carpinteiro, A.; Edwards, M.J.; Hoffmann, M.; Ahmad, S.A.; Fassbender, K.; Gulbins, E. Pharmacological Inhibition of Acid Sphingomyelinase Prevents Uptake of SARS-CoV-2 by Epithelial Cells. Cell Rep. Med. 2020, 1, 100142. [CrossRef]

102. Schloer, S.; Brunotte, L.; Goretzko, J.; Mecate-Zambrano, A.; Korthals, N.; Gerke, V.; Ludwig, S.; Rescher, U. Targeting the Endolysosomal Host-SARS-CoV-2 Interface by Clinically Licensed Functional Inhibitors of Acid Sphingomyelinase (FIASMA) Including the Antidepressant Fluoxetine. Emerg. Microbes Infect. 2020, 9, 2245-2255. [CrossRef]

103. le Corre, P.; Loas, G. Repurposing Functional Inhibitors of Acid Sphingomyelinase (Fiasmas): An Opportunity against SARS-CoV2 Infection? J. Clin. Pharm. Ther. 2021, 1-7. [CrossRef]

104. Horinouchi, K.; Erlich, S.; Perl, D.P.; Ferlinz, K.; Bisgaier, C.L.; Sandhoff, K.; Desnick, R.J.; Stewart, C.L.; Schuchman, E.H. Acid Sphingomyelinase Deficient Mice: A Model of Types A and B Niemann-Pick Disease. Nat. Genet. 1995, 10, 288-293. [CrossRef]

105. Kuzu, O.F.; Gowda, R.; Noory, M.A.; Robertson, G.P. Modulating Cancer Cell Survival by Targeting Intracellular Cholesterol Transport. Br. J. Cancer 2017, 117, 513-524. [CrossRef]

106. Naser, E.; Kadow, S.; Schumacher, F.; Mohamed, Z.H.; Kappe, C.; Hessler, G.; Pollmeier, B.; Kleuser, B.; Arenz, C.; Becker, K.A.; et al. Characterization of the Small Molecule ARC39, a Direct and Specific Inhibitor of Acid Sphingomyelinase in Vitro. J. Lipid Res. 2020, 61, 896-910. [CrossRef] [PubMed]

107. Prause, K.; Naseri, G.; Schumacher, F.; Kappe, C.; Kleuser, B.; Arenz, C. A Photocaged Inhibitor of Acid Sphingomyelinase. Chem. Commun. 2020, 56, 14885-14888. [CrossRef]

108. Börtlein, C.; Schumacher, F.; Kleuser, B.; Dölken, L.; Avota, E. Role of Neutral Sphingomyelinase-2 (Nsm 2) in the Control of $t$ Cell Plasma Membrane Lipid Composition and Cholesterol Homeostasis. Front. Cell Dev. Biol. 2019, 7, 226. [CrossRef]

109. Mizrachi, A.; Ben-Aharon, I.; Li, H.; Bar-Joseph, H.; Bodden, C.; Hikri, E.; Popovtzer, A.; Shalgi, R.; Haimovitz-Friedman, A. Chemotherapy-Induced Acute Vascular Injury Involves Intracellular Generation of ROS via Activation of the Acid Sphingomyelinase Pathway. Cell. Signal. 2021, 82, 109969. [CrossRef]

110. Rajagopal, C.; Harikumar, K.B. The Origin and Functions of Exosomes in Cancer. Front. Oncol. 2018, 8, 66. [CrossRef] [PubMed] 
111. Kunou, S.; Shimada, K.; Takai, M.; Sakamoto, A.; Aoki, T.; Hikita, T.; Kagaya, Y.; Iwamoto, E.; Sanada, M.; Shimada, S.; et al. Exosomes Secreted from Cancer-Associated Fibroblasts Elicit Anti-Pyrimidine Drug Resistance through Modulation of Its Transporter in Malignant Lymphoma. Oncogene 2021, 40, 3989-4003. [CrossRef]

112. Li, S.; Yi, M.; Dong, B.; Jiao, Y.; Luo, S.; Wu, K. The Roles of Exosomes in Cancer Drug Resistance and Its Therapeutic Application. Clin. Transl. Med. 2020, 10, e257. [CrossRef]

113. Kosaka, N.; Iguchi, H.; Hagiwara, K.; Yoshioka, Y.; Takeshita, F.; Ochiya, T. Neutral Sphingomyelinase 2 (NSMase2)-Dependent Exosomal Transfer of Angiogenic Micrornas Regulate Cancer Cell Metastasis. J. Biol. Chem. 2013, 288, 10849-10859. [CrossRef]

114. Lin, M.; Liao, W.; Dong, M.; Zhu, R.; Xiao, J.; Sun, T.; Chen, Z.; Wu, B.; Jin, J. Exosomal Neutral Sphingomyelinase 1 Suppresses Hepatocellular Carcinoma via Decreasing the Ratio of Sphingomyelin/Ceramide. FEBS J. 2018, 285, 3835-3848. [CrossRef] [PubMed]

115. Gurunathan, S.; Kang, M.H.; Jeyaraj, M.; Kim, J.H. Platinum Nanoparticles Enhance Exosome Release in Human Lung Epithelial Adenocarcinoma Cancer Cells (A549): Oxidative Stress and the Ceramide Pathway Are Key Players. Int. J. Nanomed. 2021, 16, 515-538. [CrossRef]

116. Chen, Y.; Cao, Y. The Sphingomyelin Synthase Family: Proteins, Diseases, and Inhibitors. Biol. Chem. 2017, 398, 1319-1325. [CrossRef] [PubMed]

117. Gulbins, A.; Schumacher, F.; Becker, K.A.; Wilker, B.; Soddemann, M.; Boldrin, F.; Müller, C.P.; Edwards, M.J.; Goodman, M.; Caldwell, C.C.; et al. Antidepressants Act by Inducing Autophagy Controlled by Sphingomyelin-Ceramide. Mol. Psychiatry 2018, 23, 2324-2346. [CrossRef]

118. Barceló-Coblijn, G.; Martin, M.L.; de Almeida, R.F.M.; Noguera-Salvà, M.A.; Marcilla-Etxenike, A.; Guardiola-Serrano, F.; Lüth, A.; Kleuser, B.; Halver, J.E.; Escribá, P.v. Sphingomyelin and Sphingomyelin Synthase (SMS) in the Malignant Transformation of Glioma Cells and in 2-Hydroxyoleic Acid Therapy. Proc. Natl. Acad. Sci. USA 2011, 108, 19569-19574. [CrossRef]

119. Deng, Y.; Hu, J.C.; He, S.H.; Lou, B.; Ding, T.B.; Yang, J.T.; Mo, M.G.; Ye, D.Y.; Zhou, L.; Jiang, X.C.; et al. Sphingomyelin Synthase 2 Facilitates M2-like Macrophage Polarization and Tumor Progression in a Mouse Model of Triple-Negative Breast Cancer. Acta Pharmacol. Sin. 2021, 42, 149-159. [CrossRef]

120. Jing, F.; Jing, C.; Dai, X.; Zhou, G.; Di, S.; Bi, X.; Dai, T.; Qin, T.; Hong, L. Sphingomyelin Synthase 2 but Not Sphingomyelin Synthase 1 Is Upregulated in Ovarian Cancer and Involved in Migration, Growth and Survival via Different Mechanisms. Am. J. Transl. Res. 2021, 13, 4412-4421. [PubMed]

121. Zheng, K.; Chen, Z.; Feng, H.; Chen, Y.; Zhang, C.; Yu, J.; Luo, Y.; Zhao, L.; Jiang, X.; Shi, F. Sphingomyelin Synthase 2 Promotes an Aggressive Breast Cancer Phenotype by Disrupting the Homoeostasis of Ceramide and Sphingomyelin. Cell Death Dis. 2019, 10, 1-11. [CrossRef]

122. Bilal, F.; Montfort, A.; Gilhodes, J.; Garcia, V.; Riond, J.; Carpentier, S.; Filleron, T.; Colacios, C.; Levade, T.; Daher, A.; et al. Sphingomyelin Synthase 1 (SMS1) Downregulation Is Associated with Sphingolipid Reprogramming and a Worse Prognosis in Melanoma. Front. Pharmacol. 2019, 10, 443. [CrossRef]

123. Song, M.; Zang, W.; Zhang, B.; Cao, J.; Yang, G. GCS Overexpression Is Associated with Multidrug Resistance of Human HCT-8 Colon Cancer Cells. J. Exp. Clin. Cancer Res. 2012, 31, 1-6. [CrossRef] [PubMed]

124. Liu, J.; Wang, S.; Wang, C.; Kong, X.; Sun, P. Prognostic Value of Using Glucosylceramide Synthase and Cytochrome P450 Family 1 Subfamily A1 Expression Levels for Patients with Triple-negative Breast Cancer Following Neoadjuvant Chemotherapy. Exp. Ther. Med. 2021, 21, 1. [CrossRef]

125. Lee, J.Y.; Nam, M.; Son, H.Y.; Hyun, K.; Jang, S.Y.; Kim, J.W.; Kim, M.W.; Jung, Y.; Jang, E.; Yoon, S.J.; et al. Polyunsaturated Fatty Acid Biosynthesis Pathway Determines Ferroptosis Sensitivity in Gastric Cancer. Proc. Natl. Acad. Sci. USA 2020, 117, 32433-32442. [CrossRef]

126. Gouazé, V.; Liu, Y.Y.; Prickett, C.S.; Yu, J.Y.; Giuliano, A.E.; Cabot, M.C. Glucosylceramide Synthase Blockade Down-Regulates P-Glycoprotein and Resensitizes Multidrug-Resistant Breast Cancer Cells to Anticancer Drugs. Cancer Res. 2005, 65, 3861-3867. [CrossRef]

127. Madigan, J.P.; Robey, R.W.; Poprawski, J.E.; Huang, H.; Clarke, C.J.; Gottesman, M.M.; Cabot, M.C.; Rosenberg, D.W. A Role for Ceramide Glycosylation in Resistance to Oxaliplatin in Colorectal Cancer. Exp. Cell Res. 2020, 388, 111860. [CrossRef]

128. Snider, A.J.; Seeds, M.C.; Johnstone, L.; Snider, J.M.; Hallmark, B.; Dutta, R.; Franco, C.M.; Parks, J.S.; Bensen, J.T.; Broeckling, C.D.; et al. Identification of Plasma Glycosphingolipids as Potential Biomarkers for Prostate Cancer (PCA) Status. Biomolecules 2020, 10, 1393. [CrossRef]

129. Hartwig, P.; Höglinger, D. The Glucosylceramide Synthase Inhibitor PDMP Causes Lysosomal Lipid Accumulation and MTOR Inactivation. Int. J. Mol. Sci. 2021, 22, 7065. [CrossRef]

130. Ortega, R.A.; Wang, C.; Raymond, D.; Bryant, N.; Scherzer, C.R.; Thaler, A.; Alcalay, R.N.; West, A.B.; Mirelman, A.; Kuras, Y.; et al. Association of Dual LRRK2 G2019S and GBA Variations with Parkinson Disease Progression. JAMA Netw. Open 2021, 4, 215845. [CrossRef]

131. Gan-Or, Z.; Liong, C.; Alcalay, R.N. GBA-Associated Parkinson's Disease and Other Synucleinopathies. Curr. Neurol. Neurosci. Rep. 2018, 18, 1-10. [CrossRef] [PubMed]

132. Astudillo, L.; Therville, N.; Colacios, C.; Ségui, B.; Andrieu-Abadie, N.; Levade, T. Glucosylceramidases and Malignancies in Mammals. Biochimie 2016, 125, 267-280. [CrossRef] [PubMed] 
133. Sturchio, A.; Dwivedi, A.K.; Vizcarra, J.A.; Chirra, M.; Keeling, E.G.; Mata, I.F.; Kauffman, M.A.; Pandey, M.K.; Roviello, G.; Comi, C.; et al. Genetic Parkinsonisms and Cancer: A Systematic Review and Meta-Analysis. Rev. Neurosci. 2021, 32, $159-167$. [CrossRef] [PubMed]

134. Li, Z.; Xu, D.; Tong, X.; Shan, C. Inhibition of $\beta$-Glucosidase Overcomes Gastric Cancer Chemoresistance through Inducing Lysosomal Dysfunction. Clin. Res. Hepatol. Gastroenterol. 2021, 45, 101456. [CrossRef]

135. Vijayan, Y.; Lankadasari, M.B.; Harikumar, K.B. Acid Ceramidase: A Novel Therapeutic Target in Cancer. Curr. Top. Med. Chem. 2019, 19, 1512-1520. [CrossRef]

136. Saied, E.M.; Arenz, C. Inhibitors of Ceramidases. Chem. Phys. Lipids 2016, 197, 60-68. [CrossRef]

137. Lai, M.; La Rocca, V.; Amato, R.; Freer, G.; Costa, M.; Spezia, P.G.; Quaranta, P.; Lombardo, G.; Piomelli, D.; Pistello, M. Ablation of Acid Ceramidase Impairs Autophagy and Mitochondria Activity in Melanoma Cells. Int. J. Mol. Sci. 2021, 22, 3247. [CrossRef]

138. Lai, M.; Amato, R.; La Rocca, V.; Bilgin, M.; Freer, G.; Spezia, P.; Quaranta, P.; Piomelli, D.; Pistello, M. Acid Ceramidase Controls Apoptosis and Increases Autophagy in Human Melanoma Cells Treated with Doxorubicin. Sci. Rep. 2021, 11, 1-14. [CrossRef]

139. Clifford, R.E.; Govindarajah, N.; Bowden, D.; Sutton, P.; Glenn, M.; Darvish-Damavandi, M.; Buczacki, S.; McDermott, U.; Szulc, Z.; Ogretmen, B.; et al. Targeting Acid Ceramidase to Improve the Radiosensitivity of Rectal Cancer. Cells 2020, 9, 2693. [CrossRef]

140. White-Gilbertson, S.; Lu, P.; Jones, C.M.; Chiodini, S.; Hurley, D.; Das, A.; Delaney, J.R.; Norris, J.S.; Voelkel-Johnson, C. Tamoxifen Is a Candidate First-in-Class Inhibitor of Acid Ceramidase That Reduces Amitotic Division in Polyploid Giant Cancer Cells-Unrecognized Players in Tumorigenesis. Cancer Med. 2020, 9, 3142-3152. [CrossRef]

141. Rothemund, M.; Bär, A.; Klatt, F.; Weidler, S.; Köhler, L.; Unverzagt, C.; Kuhn, C.D.; Schobert, R. N-Metallocenoylsphingosines as Targeted Ceramidase Inhibitors: Syntheses and Antitumoral Effects. Bioorg. Chem. 2020, 97, 103703. [CrossRef]

142. Liu, B.; Xiao, J.; Dong, M.; Qiu, Z.; Jin, J. Human Alkaline Ceramidase 2 Promotes the Growth, Invasion, and Migration of Hepatocellular Carcinoma Cells via Sphingomyelin Phosphodiesterase Acid-like 3B. Cancer Sci. 2020, 111, 2259. [CrossRef] [PubMed]

143. Zhang, S.; Huang, P.; Dai, H.; Li, Q.; Hu, L.; Peng, J.; Jiang, S.; Xu, Y.; Wu, Z.; Nie, H.; et al. TIMELESS Regulates Sphingolipid Metabolism and Tumor Cell Growth through Sp1/ACER2/S1P Axis in ER-Positive Breast Cancer. Cell Death Dis. 2020, 11, 1-14. [CrossRef]

144. Yin, Y.; Xu, M.; Gao, J.; Li, M. Alkaline Ceramidase 3 Promotes Growth of Hepatocellular Carcinoma Cells via Regulating S1P/S1PR2/PI3K/AKT Signaling. Pathol. Res. Pract. 2018, 214, 1381-1387. [CrossRef]

145. Steiner, R.; Saied, E.M.; Othman, A.; Arenz, C.; Maccarone, A.T.; Poad, B.L.J.; Blanksby, S.J.; von Eckardstein, A.; Hornemann, T. Elucidating the Chemical Structure of Native 1-Deoxysphingosine. J. Lipid Res. 2016, 57, 1194-1203. [CrossRef]

146. Saied, E.M.; Le, T.L.S.; Hornemann, T.; Arenz, C. Synthesis and Characterization of Some Atypical Sphingoid Bases. Bioorg. Med. Chem. 2018, 26, 4047-4057. [CrossRef]

147. Bielsa, N.; Casasampere, M.; Aseeri, M.; Casas, J.; Delgado, A.; Abad, J.L.; Fabriàs, G. Discovery of Deoxyceramide Analogs as Highly Selective ACER3 Inhibitors in Live Cells. Eur. J. Med. Chem. 2021, 216, 113296. [CrossRef]

148. Vasiliauskaité-Brooks, I.; Healey, R.D.; Rochaix, P.; Saint-Paul, J.; Sounier, R.; Grison, C.; Waltrich-Augusto, T.; Fortier, M.; Hoh, F.; Saied, E.M.; et al. Structure of a Human Intramembrane Ceramidase Explains Enzymatic Dysfunction Found in Leukodystrophy. Nat. Commun. 2018, 9, 1-13. [CrossRef]

149. Sakamoto, W.; Coant, N.; Canals, D.; Obeid, L.M.; Hannun, Y.A. Functions of Neutral Ceramidase in the Golgi Apparatus. J. Lipid Res. 2018, 59, 2116-2125. [CrossRef]

150. García-Barros, M.; Coant, N.; Kawamori, T.; Wada, M.; Snider, A.J.; Truman, J.-P.; Wu, B.X.; Furuya, H.; Clarke, C.J.; Bialkowska, A.B.; et al. Role of Neutral Ceramidase in Colon Cancer. FASEB J. 2016, 30, 4159. [CrossRef]

151. Coant, N.; García-Barros, M.; Zhang, Q.; Obeid, L.M.; Hannun, Y.A. AKT as a Key Target for Growth Promoting Functions of Neutral Ceramidase in Colon Cancer Cells. Oncogene 2018, 37, 3852-3863. [CrossRef] [PubMed]

152. Pfeiler, G.; Hudelist, G.; Wülfing, P.; Mattsson, B.; Königsberg, R.; Kubista, E.; Singer, C.F. Impact of AdipoR1 Expression on Breast Cancer Development. Gynecol. Oncol. 2010, 117, 134-138. [CrossRef]

153. Ye, J.; Jiang, L.; Wu, C.; Liu, A.; Mao, S.; Ge, L. Three ADIPOR1 Polymorphisms and Cancer Risk: A Meta-Analysis of Case-Control Studies. PLoS ONE 2015, 10, e0127253. [CrossRef] [PubMed]

154. Kordafshari, M.; Nourian, M.; Mehrvar, N.; Jalaeikhoo, H.; Etemadi, A.; Khoshdel, A.R.; Idris, M.G.; Iravani, S.; Mehrvar, A. Expression of AdipoR1 and AdipoR2 and Serum Level of Adiponectin in Gastric Cancer. Gastrointest. Tumors 2020, 7, 103-109. [CrossRef]

155. Bui, K.C.; Nguyen, M.L.T.; Barat, S.; Chen, X.; Bhuria, V.; Xing, J.; Nguyen, L.T.; Le, H.S.; Velavan, T.P.; Wilkens, L.; et al. Effect of AdipoR Agonist in Cholangiocarcinoma. J. Clin. Oncol. 2018, 36, 323. [CrossRef]

156. Philp, L.K.; Rockstroh, A.; Lehman, M.; Sadowski, M.C.; Bartonicek, N.; Wade, J.D.; Otvos, L.; Nelson, C.C. Adiponectin Receptor Activation Inhibits Prostate Cancer Xenograft Growth. Endocr. Relat. Cancer 2020, 27, 711-729. [CrossRef]

157. Akimoto, M.; Maruyama, R.; Kawabata, Y.; Tajima, Y.; Takenaga, K. Antidiabetic Adiponectin Receptor Agonist AdipoRon Suppresses Tumour Growth of Pancreatic Cancer by Inducing RIPK1/ERK-Dependent Necroptosis. Cell Death Dis. 2018, 9, 1-18. [CrossRef] [PubMed]

158. Vasiliauskaité-Brooks, I.; Sounier, R.; Rochaix, P.; Bellot, G.; Fortier, M.; Hoh, F.; de Colibus, L.; Bechara, C.; Saied, E.M.; Arenz, C.; et al. Structural Insights into Adiponectin Receptors Suggest Ceramidase Activity. Nature 2017, 544, 120-123. [CrossRef] 
159. Lee, M.J.; van Brocklyn, J.R.; Thangada, S.; Liu, C.H.; Hand, A.R.; Menzeleev, R.; Spiegel, S.; Hla, T. Sphingosine-1-Phosphate as a Ligand for the G Protein-Coupled Receptor EDG-1. Science 1998, 279, 1552-1555. [CrossRef] [PubMed]

160. MacEyka, M.; Spiegel, S. Sphingolipid Metabolites in Inflammatory Disease. Nature 2014, 510, 58-67. [CrossRef]

161. Ratajczak, M.Z.; Lee, H.; Wysoczynski, M.; Wan, W.; Marlicz, W.; Laughlin, M.J.; Kucia, M.; Janowska-Wieczorek, A.; Ratajczak, J. Novel insight into stem cell mobilization-plasma sphingosine-1-phosphate is a major chemoattractant that directs the egress of hematopoietic stem progenitor cells from the bone marrow and its level in peripheral blood increases during mobilization due to activation of complement cascade/membrane attack complex. Leukemia 2010, 24, 976-985.

162. Spiegel, S.; Milstien, S. The Outs and the Ins of Sphingosine-1-Phosphate in Immunity. Nat. Rev. Immunol. 2011, 11, 403-415. [CrossRef]

163. Fyrst, H.; Saba, J.D. An Update on Sphingosine-1-Phosphate and Other Sphingolipid Mediators. Nat. Chem. Biol. 2010, 6, 489-497. [CrossRef]

164. Shida, D.; Takabe, K.; Kapitonov, D.; Milstien, S.; Spiegel, S. Targeting SphK1 as a New Strategy against Cancer. Curr. Drug Targets 2008, 9, 662-673. [CrossRef]

165. Pyne, N.J.; Tonelli, F.; Lim, K.G.; Long, J.S.; Edwards, J.; Pyne, S. Sphingosine 1-Phosphate Signalling in Cancer. Biochem. Soc. Trans. 2012, 40, 94-100. [CrossRef]

166. Peters, S.L.; Alewijnse, A.E. Sphingosine-1-Phosphate Signaling in the Cardiovascular System. Curr. Opin. Pharmacol. 2007, 7, 186-192. [CrossRef]

167. Pyne, S.; Pyne, N.J. Sphingosine 1-Phosphate Signalling in Mammalian Cells. Biochem. J. 2000, 349, 385-402. [CrossRef]

168. Donati, C.; Meacci, E.; Nuti, F.; Becciolini, L.; Farnararo, M.; Bruni, P. Sphingosine 1-Phosphate Regulates Myogenic Differentiation: A Major Role for S1P2 Receptor. FASEB J. 2005, 19, 449-451. [CrossRef]

169. Bruni, P.; Donati, C. Pleiotropic Effects of Sphingolipids in Skeletal Muscle. Cell. Mol. Life Sci. 2008, 65, 3725-3736. [CrossRef]

170. Maceyka, M.; Harikumar, K.B.; Milstien, S.; Spiegel, S. Sphingosine-1-Phosphate Signaling and Its Role in Disease. Trends Cell Biol. 2012, 22, 50-60. [CrossRef]

171. Maceyka, M.; Rohrbach, T.; Milstien, S.; Spiegel, S. Role of Sphingosine Kinase 1 and Sphingosine-1-Phosphate Axis in Hepatocellular Carcinoma. Handb. Exp. Pharmacol. 2020, 259, 3-17. [CrossRef] [PubMed]

172. Hammad, S.M.; Crellin, H.G.; Wu, B.X.; Melton, J.; Anelli, V.; Obeid, L.M. Dual and Distinct Roles for Sphingosine Kinase 1 and Sphingosine 1 Phosphate in the Response to Inflammatory Stimuli in RAW Macrophages. Prostaglandins Other Lipid Mediat. 2008, 85, 107-114. [CrossRef] [PubMed]

173. Albinet, V.; Bats, M.L.; Huwiler, A.; Rochaix, P.; Chevreau, C.; Ségui, B.; Levade, T.; Andrieu-Abadie, N. Dual Role of Sphingosine Kinase-1 in Promoting the Differentiation of Dermal Fibroblasts and the Dissemination of Melanoma Cells. Br. Dent. J. 2014, 217, 3364-3373. [CrossRef]

174. Simon, J.; Ouro, A.; Ala-Ibanibo, L.; Presa, N.; Delgado, T.C.; Martínez-Chantar, M.L. Sphingolipids in Non-Alcoholic Fatty Liver Disease and Hepatocellular Carcinoma: Ceramide Turnover. Int. J. Mol. Sci. 2020, 21, 40. [CrossRef]

175. Schneider, G.; Sellers, Z.P.; Bujko, K.; Kakar, S.S.; Kucia, M.; Ratajczak, M.Z. Novel Pleiotropic Effects of Bioactive Phospholipids in Human Lung Cancer Metastasis. Oncotarget 2017, 8, 58247-58263. [CrossRef]

176. Ushitora, Y.; Tashiro, H.; Ogawa, T.; Tanimoto, Y.; Kuroda, S.; Kobayashi, T.; Miyata, Y.; Itamoto, T.; Asahara, T.; Ohdan, H. Suppression of Hepatocellular Carcinoma Recurrence after Rat Liver Transplantation by FTY720, a Sphingosine-1-Phosphate Analog. Transplantation 2009, 88, 980-986. [CrossRef]

177. Budkowska, M.; Ostrycharz, E.; Wojtowicz, A.; Marcinowska, Z.; Woźniak, J.; Ratajczak, M.Z.; Dołęgowska, B. A Circadian Rhythm in Both Complement Cascade (ComC) Activation and Sphingosine-1-Phosphate (S1P) Levels in Human Peripheral Blood Supports a Role for the ComC-S1P Axis in Circadian Changes in the Number of Stem Cells Circulating in Peripheral Blood. Stem Cell Rev. Rep. 2015, 14, 677-685. [CrossRef]

178. Sukocheva, O.A.; Furuya, H.; Ng, M.L.; Friedemann, M.; Menschikowski, M.; Tarasov, V.V.; Chubarev, V.N.; Klochkov, S.G.; Neganova, M.E.; Mangoni, A.A.; et al. Sphingosine Kinase and Sphingosine-1-Phosphate Receptor Signaling Pathway in Inflammatory Gastrointestinal Disease and Cancers: A Novel Therapeutic Target. Pharmacol. Ther. 2020, 207, 107464. [CrossRef]

179. Liu, H.; Toman, R.E.; Goparaju, S.K.; Maceyka, M.; Nava, V.E.; Sankala, H.; Payner, S.G.; Bektas, M.; Ishii, I.; Chun, J.; et al. Sphingosine Kinase Type 2 Is a Putative BH3-Only Protein That Induces Apoptosis. J. Biol. Chem. 2003, 278, 40330-40336. [CrossRef] [PubMed]

180. Igarashi, N.; Okada, T.; Hayashi, S.; Fujita, T.; Jahangeer, S.; Nakamura, S.I. Sphingosine Kinase 2 Is a Nuclear Protein and Inhibits DNA Synthesis. J. Biol. Chem. 2003, 278, 46832-46839. [CrossRef] [PubMed]

181. Okada, T.; Ding, G.; Sonoda, H.; Kajimoto, T.; Haga, Y.; Khosrowbeygi, A.; Gao, S.; Miwa, N.; Jahangeer, S.; Nakamura, S.I. Involvement of N-Terminal-Extended Form of Sphingosine Kinase 2 in Serum-Dependent Regulation of Cell Proliferation and Apoptosis. J. Biol. Chem. 2005, 280, 36318-36325. [CrossRef] [PubMed]

182. Sankala, H.M.; Hait, N.C.; Paugh, S.W.; Shida, D.; Lépine, S.; Elmore, L.W.; Dent, P.; Milstien, S.; Spiegel, S. Involvement of Sphingosine Kinase 2 in P53-Independent Induction of P21 by the Chemotherapeutic Drug Doxorubicin. Cancer Res. 2007, 67, 10466-10474. [CrossRef] [PubMed]

183. Xu, D.; Zhu, H.; Wang, C.; Zhao, W.; Liu, G.; Bao, G.; Cui, D.; Fan, J.; Wang, F.; Jin, H.; et al. SphK2 Over-Expression Promotes Osteosarcoma Cell Growth. Oncotarget 2017, 8, 105525-105535. [CrossRef] [PubMed] 
184. van Brooklyn, J.R.; Jackson, C.A.; Pearl, D.K.; Kotur, M.S.; Snyder, P.J.; Prior, T.W. Sphingosine Kinase-1 Expression Correlates with Poor Survival of Patients with Glioblastoma Multiforme: Roles of Sphingosine Kinase Isoforms in Growth of Glioblastoma Cell Lines. J. Neuropathol. Exp. Neurol. 2005, 64, 695-705. [CrossRef]

185. Yang, J.; Yang, C.; Zhang, S.; Mei, Z.; Shi, M.; Sun, S.; Shi, L.; Wang, Z.; Wang, Y.; Li, Z.; et al. ABC294640, a Sphingosine Kinase 2 Inhibitor, Enhances the Antitumor Effects of TRAIL in Non-Small Cell Lung Cancer. Cancer Biol. Ther. 2015, 16, 1194-1204. [CrossRef]

186. Beider, K.; Rosenberg, E.; Bitner, H.; Shimoni, A.; Leiba, M.; Koren-Michowitz, M.; Ribakovsky, E.; Klein, S.; Olam, D.; Weiss, L.; et al. The Sphingosine-1-Phosphate Modulator FTY720 Targets Multiple Myeloma via the CXCR4/CXCL12 Pathway. Clinical Cancer Res. 2017, 23, 1733-1747. [CrossRef] [PubMed]

187. White, C.; Alshaker, H.; Cooper, C.; Winkler, M.; Pchejetski, D. The Emerging Role of FTY720 (Fingolimod) in Cancer Treatment. Oncotarget 2016, 7, 23106-23127. [CrossRef]

188. Tonelli, F.; Lim, K.G.; Loveridge, C.; Long, J.; Pitson, S.M.; Tigyi, G.; Bittman, R.; Pyne, S.; Pyne, N.J. FTY720 and (S)-FTY720 Vinylphosphonate Inhibit Sphingosine Kinase 1 and Promote Its Proteasomal Degradation in Human Pulmonary Artery Smooth Muscle, Breast Cancer and Androgen-Independent Prostate Cancer Cells. Cell. Signal. 2010, 22, 1536-1542. [CrossRef]

189. Ouro, A.; Arana, L.; Gangoiti, P.; Rivera, I.G.; Ordoñez, M.; Trueba, M.; Lankalapalli, R.S.; Bittman, R.; Gomez-Muñoz, A. Ceramide 1-Phosphate Stimulates Glucose Uptake in Macrophages. Cell. Signal. 2013, 25, 786-795. [CrossRef]

190. Halmer, R.; Walter, S.; Faßbender, K. Sphingolipids: Important Players in Multiple Sclerosis. Cell. Physiol. Biochem. 2014, 34, 111-118. [CrossRef]

191. Brinkmann, V. FTY720 (Fingolimod) in Multiple Sclerosis: Therapeutic Effects in the Immune and the Central Nervous System. Br. J. Pharmacol. 2009, 158, 1173-1182. [CrossRef] [PubMed]

192. Copland, D.A.; Liu, J.; Schewitz-Bowers, L.P.; Brinkmann, V.; Anderson, K.; Nicholson, L.B.; Dick, A.D. Therapeutic Dosing of Fingolimod (FTY720) Prevents Cell Infiltration, Rapidly Suppresses Ocular Inflammation, and Maintains the Blood-Ocular Barrier. Am. J. Pathol. 2012, 180, 672-681. [CrossRef]

193. Epstein, D.J.; Dunn, J.; Deresinski, S. Infectious Complications of Multiple Sclerosis Therapies: Implications for Screening, Prophylaxis, and Management. Open Forum Infect. Dis. 2018, 5, ofy174. [CrossRef]

194. Kapitonov, D.; Allegood, J.C.; Mitchell, C.; Hait, N.C.; Almenara, J.A.; Adams, J.K.; Zipkin, R.E.; Dent, P.; Kordula, T.; Milstien, S.; et al. Targeting Sphingosine Kinase 1 Inhibits Akt Signaling, Induces Apoptosis, and Suppresses Growth of Human Glioblastoma Cells and Xenografts. Cancer Res. 2009, 69, 6915-6923. [CrossRef] [PubMed]

195. Chen, K.; Pan, Q.; Gao, Y.; Yang, X.; Wang, S.; Peppelenbosch, M.P.; Kong, X. DMS Triggers Apoptosis Associated with the Inhibition of SPHK1/NF-KB Activation and Increase in Intracellular Ca2+ Concentration in Human Cancer Cells. Int. J. Mol. Med. 2014, 33, 17-24. [CrossRef] [PubMed]

196. Hii, L.W.; Chung, F.F.L.; Mai, C.W.; Yee, Z.Y.; Chan, H.H.; Raja, V.J.; Dephoure, N.E.; Pyne, N.J.; Pyne, S.; Leong, C.-O. Sphingosine Kinase 1 Regulates the Survival of Breast Cancer Stem Cells and Non-Stem Breast Cancer Cells by Suppression of STAT1. Cells 2020, 9, 886. [CrossRef]

197. Trayssac, M.; Clarke, C.J.; Stith, J.L.; Snider, J.M.; Newen, N.; Gault, C.R.; Hannun, Y.A.; Obeid, L.M. Targeting Sphingosine Kinase 1 (SK1) Enhances Oncogene-Induced Senescence through Ceramide Synthase 2 (CerS2)-Mediated Generation of Very-Long-Chain Ceramides. Cell Death Dis. 2021, 12, 1-15. [CrossRef] [PubMed]

198. Cartier, A.; Hla, T. Sphingosine 1-Phosphate: Lipid Signaling in Pathology and Therapy. Science 2019, 366. [CrossRef] [PubMed]

199. Pyne, N.J.; Pyne, S. Recent Advances in the Role of Sphingosine 1-phosphate in Cancer. FEBS Lett. 2020, 594, 3583-3601. [CrossRef]

200. Pyne, S.; Kong, K.C.; Darroch, P.I. Lysophosphatidic Acid and Sphingosine 1-Phosphate Biology: The Role of Lipid Phosphate Phosphatases. Semin. Cell Dev. Biol. 2004, 15, 491-501. [CrossRef] [PubMed]

201. Brindley, D.N.; English, D.; Pilquil, C.; Buri, K.; Ling, Z.C. Lipid Phosphate Phosphatases Regulate Signal Transduction through Glycerolipids and Sphingolipids. Biochim. Biophys. Acta 2002, 1582, 33-44. [CrossRef]

202. Mandala, S.M. Sphingosine-1-Phosphate Phosphatases. Prostaglandins Other Lipid Mediat. 2001, 64, 143-156. [CrossRef]

203. Allende, M.L.; Sipe, L.M.; Tuymetova, G.; Wilson-Henjum, K.L.; Chen, W.; Proia, R.L. Sphingosine-1-Phosphate Phosphatase 1 Regulates Keratinocyte Differentiation and Epidermal Homeostasis. J. Biol. Chem. 2013, 288, 18381-18391. [CrossRef]

204. Huang, W.; Liang, J.; Nagahashi, M.; Avni, D.; Yamada, A.; Maceyka, M.; Wolen, A.R.; Kordula, T.; Milstien, S.; Takabe, K.; et al. Sphingosine-1-phosphate Phosphatase 2 Promotes Disruption of Mucosal Integrity, and Contributes to Ulcerative Colitis in Mice and Humans. FASEB J. 2016, 30, 2945-2958. [CrossRef] [PubMed]

205. Taguchi, Y.; Allende, M.L.; Mizukami, H.; Cook, E.K.; Gavrilova, O.; Tuymetova, G.; Clarke, B.A.; Chen, W.; Olivera, A.; Proia, R.L. Sphingosine-1-Phosphate Phosphatase 2 Regulates Pancreatic Islet-Cell Endoplasmic Reticulum Stress and Proliferation. J. Biol. Chem. 2016, 291, 12029-12038. [CrossRef] [PubMed]

206. Gao, X.Y.; Li, L.; Wang, X.H.; Wen, X.Z.; Ji, K.; Ye, L.; Cai, J.; Jiang, W.G.; Ji, J.F. Inhibition of Sphingosine-1-Phosphate Phosphatase 1 Promotes Cancer Cells Migration in Gastric Cancer: Clinical Implications. Oncol. Rep. 2015, 34, 1977-1987. [CrossRef] [PubMed]

207. le Stunff, H.; Mikami, A.; Giussani, P.; Hobson, J.P.; Jolly, P.S.; Milstien, S.; Spiegel, S. Role of Sphingosine-1-Phosphate Phosphatase 1 in Epidermal Growth Factor-Induced Chemotaxis. J. Biol. Chem. 2004, 279, 34290-34297. [CrossRef] [PubMed]

208. Bao, Y.; Chen, Z.; Guo, Y.; Feng, Y.; Li, Z.; Han, W.; Wang, J.; Zhao, W.; Jiao, Y.; Li, K.; et al. Tumor Suppressor MicroRNA-27a in Colorectal Carcinogenesis and Progression by Targeting SGPP1 and Smad2. PLoS ONE 2014, 9, e105991. [CrossRef] [PubMed] 
209. Hannun, Y.A.; Obeid, L.M. Sphingolipids and Their Metabolism in Physiology and Disease. Nat. Rev. Mol. Cell Biol. 2018, 19, 175-191. [CrossRef]

210. Pulkoski-Gross, M.J.; Donaldson, J.C.; Obeid, L.M. Sphingosine-1-Phosphate Metabolism: A Structural Perspective. Crit. Rev. Biochem. Mol. Biol. 2015, 50, 298-313. [CrossRef]

211. Pyne, N.J.; Pyne, S. Sphingosine 1-Phosphate and Cancer. Nat. Rev. Cancer 2010, 10, 489. [CrossRef] [PubMed]

212. Gomez-Munoz, A.; Duffy, P.A.; Martin, A.; O’Brien, L.; Byun, H.S.; Bittman, R.; Brindley, D.N. Short-Chain Ceramide-1-Phosphates Are Novel Stimulators of DNA Synthesis and Cell Division: Antagonism by Cell-Permeable Ceramides. Mol. Pharmacol. 1995, 47, 833-839. [PubMed]

213. Gomez-Munoz, A.; Frago, L.M.; Alvarez, L.; Varela-Nieto, I. Stimulation of DNA Synthesis by Natural Ceramide 1-Phosphate. Biochem. J. 1997, 325, 435-440. [CrossRef]

214. Arana, L.; Gangoiti, P.; Ouro, A.; Rivera, I.G.; Ordoñez, M.; Trueba, M.; Lankalapalli, R.S.; Bittman, R.; Gomez-Muñoz, A. Generation of Reactive Oxygen Species (ROS) Is a Key Factor for Stimulation of Macrophage Proliferation by Ceramide 1Phosphate. Exp. Cell Res. 2012, 318, 350-360. [CrossRef]

215. Gangoiti, P.; Bernacchioni, C.; Donati, C.; Cencetti, F.; Ouro, A.; Gómez-Muñoz, A.; Bruni, P. Ceramide 1-Phosphate Stimulates Proliferation of C2C12 Myoblasts. Biochimie 2012, 94, 597-607. [CrossRef] [PubMed]

216. Ouro, A.; Arana, L.; Riazy, M.; Zhang, P.; Gomez-Larrauri, A.; Steinbrecher, U.; Duronio, V.; Gomez-Muñoz, A. Vascular Endothelial Growth Factor Mediates Ceramide 1-Phosphate-Stimulated Macrophage Proliferation. Exp. Cell Res. 2017, 361, 277-283. [CrossRef]

217. Gómez-Muñoz, A.; Kong, J.Y.; Salh, B.; Steinbrecher, U.P. Ceramide-1-Phosphate Blocks Apoptosis through Inhibition of Acid Sphingomyelinase in Macrophages. J. Lipid Res. 2004, 45, 99-105. [CrossRef]

218. Gomez-Munoz, A.; Kong, J.Y.; Parhar, K.; Wang, S.W.; Gangoiti, P.; Gonzalez, M.; Eivemark, S.; Salh, B.; Duronio, V.; Steinbrecher, U.P. Ceramide-1-Phosphate Promotes Cell Survival through Activation of the Phosphatidylinositol 3-Kinase/Protein Kinase B Pathway. FEBS Lett. 2005, 579, 3744-3750. [CrossRef]

219. Gangoiti, P.; Granado, M.H.; Arana, L.; Ouro, A.; Gómez-Muñoz, A. Involvement of Nitric Oxide in the Promotion of Cell Survival by Ceramide 1-Phosphate. FEBS Lett. 2008, 582, 2263-2269. [CrossRef]

220. Granado, M.H.; Gangoiti, P.; Ouro, A.; Arana, L.; Gómez-Muñoz, A. Ceramide 1-Phosphate Inhibits Serine Palmitoyltransferase and Blocks Apoptosis in Alveolar Macrophages. Biochim. Biophys. Acta 2009, 1791, 263-272. [CrossRef] [PubMed]

221. Pascuali, N.; Scotti, L.; di Pietro, M.; Oubiña, G.; Bas, D.; May, M.; Gómez Muñoz, A.; Cuasnicú, P.S.; Cohen, D.J.; Tesone, M.; et al. Ceramide-1-Phosphate Has Protective Properties against Cyclophosphamide-Induced Ovarian Damage in a Mice Model of Premature Ovarian Failure. Hum. Reprod. 2018, 33, 844-859. [CrossRef]

222. Gomez-Larrauri, A.; Ouro, A.; Trueba, M.; Gomez-Muñoz, A. Regulation of Cell Growth, Survival and Migration by Ceramide 1-Phosphate-Implications in Lung Cancer Progression and Inflammation. Cell. Signal. 2021, 83, 109980. [CrossRef]

223. Gangoiti, P.; Granado, M.H.; Arana, L.; Ouro, A.; Gomez-Muñoz, A. Activation of Protein Kinase C-Alpha Is Essential for Stimulation of Cell Proliferation by Ceramide 1-Phosphate. FEBS Lett. 2010, 584, 517-524. [CrossRef] [PubMed]

224. Gomez-Munoz, A.; Kong, J.; Salh, B.; Steinbrecher, U.P. Sphingosine-1-Phosphate Inhibits Acid Sphingomyelinase and Blocks Apoptosis in Macrophages. FEBS Lett. 2003, 539, 56-60. [CrossRef]

225. Newcomb, B.; Rhein, C.; Mileva, I.; Ahmad, R.; Clarke, C.J.; Snider, J.; Obeid, L.M.; Hannun, Y.A. Identification of an Acid Sphingomyelinase Ceramide Kinase Pathway in the Regulation of the Chemokine CCL5. J. Lipid Res. 2018, 59, 1219-1229. [CrossRef] [PubMed]

226. Mitra, P.; Maceyka, M.; Payne, S.G.; Lamour, N.; Milstien, S.; Chalfant, C.E.; Spiegel, S. Ceramide Kinase Regulates Growth and Survival of A549 Human Lung Adenocarcinoma Cells. FEBS Lett. 2007, 581, 735-740. [CrossRef] [PubMed]

227. Schwalm, S.; Erhardt, M.; Römer, I.; Pfeilschifter, J.; Zangemeister-Wittke, U.; Huwiler, A. Ceramide Kinase Is Upregulated in Metastatic Breast Cancer Cells and Contributes to Migration and Invasion by Activation of PI 3-Kinase and Akt. Int. J. Mol. Sci. 2020, 21, 1396. [CrossRef]

228. Pastukhov, O.; Schwalm, S.; Zangemeister-Wittke, U.; Fabbro, D.; Bornancin, F.; Japtok, L.; Kleuser, B.; Pfeilschifter, J.; Huwiler, A The Ceramide Kinase Inhibitor NVP-231 Inhibits Breast and Lung Cancer Cell Proliferation by Inducing M Phase Arrest and Subsequent Cell Death. Br. J. Pharmacol. 2014, 171, 5829-5844. [CrossRef]

229. Payne, A.W.; Pant, D.K.; Pan, T.C.; Chodosh, L.A. Ceramide Kinase Promotes Tumor Cell Survival and Mammary Tumor Recurrence. Cancer Res. 2014, 74, 6352-6363. [CrossRef]

230. Lamour, N.; Chalfant, C. Ceramide Kinase and the Ceramide-1-Phosphate/CPLA2 $\alpha$; Interaction as a Therapeutic Target. Curr. Drug Targets 2008, 9, 674-682. [CrossRef]

231. Berwick, M.L.; Dudley, B.A.; Maus, K.; Chalfant, C.E. The Role of Ceramide 1-Phosphate in Inflammation, Cellular Proliferation, and Wound Healing. Adv. Exp. Med. Biol. 2019, 1159, 65-77. [CrossRef]

232. Hoeferlin, L.A.; Wijesinghe, D.S.; Chalfant, C.E. The Role of Ceramide-1-Phosphate in Biological Functions. Handb. Exp. Pharmacol. 2013, 153-166. [CrossRef]

233. Baudiß, K.; de Paula Vieira, R.; Cicko, S.; Ayata, K.; Hossfeld, M.; Ehrat, N.; Gómez-Muñoz, A.; Eltzschig, H.K.; Idzko, M. C1P Attenuates Lipopolysaccharide-Induced Acute Lung Injury by Preventing NF-KB Activation in Neutrophils. J. Immunol. 2016, 196, 2319-2326. [CrossRef] [PubMed] 
234. Baudiß, K.; Ayata, C.K.; Lazar, Z.; Cicko, S.; Beckert, J.; Meyer, A.; Zech, A.; Vieira, R.P.; Bittman, R.; Gómez-Muñoz, A.; et al. Ceramide-1-Phosphate Inhibits Cigarette Smoke-Induced Airway Inflammation. Eur. Respir. J. 2015, 45, 1669-1680. [CrossRef] [PubMed]

235. Gomez-Larrauri, A.; Trueba, M.; Gomez-Muñoz, A. Potential of Ceramide 1-Phosphate as a Novel Therapeutic Agent in Pulmonary Inflammation. Expert Rev. Clin. Pharmacol. 2016, 9, 629-631. [CrossRef] [PubMed]

236. Presa, N.; Gomez-Larrauri, A.; Dominguez-Herrera, A.; Trueba, M.; Gomez-Muñoz, A. Novel Signaling Aspects of Ceramide 1-Phosphate. Biochim. Biophys. Acta Mol. Cell Biol. Lipids 2020, 1865. [CrossRef]

237. Samaha, D.; Hamdo, H.H.; Wilde, M.; Prause, K.; Arenz, C. Sphingolipid-Transporting Proteins as Cancer Therapeutic Targets. Int. J. Mol. Sci. 2019, 20, 3554. [CrossRef] [PubMed]

238. Yasuda, S.; Kitagawa, H.; Ueno, M.; Ishitani, H.; Fukasawa, M.; Nishijima, M.; Kobayashi, S.; Hanada, K. A Novel Inhibitor of Ceramide Trafficking from the Endoplasmic Reticulum to the Site of Sphingomyelin Synthesis. J. Biol. Chem. 2001, 276, 43994-44002. [CrossRef]

239. Saied, E.M.; Diederich, S.; Arenz, C. Facile Synthesis of the CERT Inhibitor HPA-12 and Some Novel Derivatives. Chem. Asian J. 2014, 9, 2092-2094. [CrossRef]

240. Berkeš, D.; Daïch, A.; Santos, C.; Ballereau, S.; Génisson, Y. Chemistry and Biology of HPAs: A Family of Ceramide Trafficking Inhibitors. Chem. A Eur. J. 2016, 22, 17514-17525. [CrossRef]

241. Nakao, N.; Ueno, M.; Sakai, S.; Egawa, D.; Hanzawa, H.; Kawasaki, S.; Kumagai, K.; Suzuki, M.; Kobayashi, S.; Hanada, K. Natural Ligand-Nonmimetic Inhibitors of the Lipid-Transfer Protein CERT. Commun. Chem. 2019, 2, 1-11. [CrossRef]

242. Samaha, D.; Hamdo, H.H.; Cong, X.; Schumacher, F.; Banhart, S.; Aglar, Ö.; Möller, H.M.; Heuer, D.; Kleuser, B.; Saied, E.M.; et al. Liposomal FRET Assay Identifies Potent Drug-Like Inhibitors of the Ceramide Transport Protein (CERT). Chem. A Eur. J. 2020, 26, 16616-16621. [CrossRef] [PubMed]

243. Castellan, T.; Santos, C.; Rodriguez, F.; Lepage, M.L.; Liang, Y.; Bodlenner, A.; Compain, P.; Génisson, Y.; Dehoux, C.; Ballereau, S. N,O-Dialkyl Deoxynojirimycin Derivatives as CERT START Domain Ligands. Bioorg. Med. Chem. Lett. 2020, $30,126796$. [CrossRef] [PubMed]

244. Lee, A.J.X.; Roylance, R.; Sander, J.; Gorman, P.; Endesfelder, D.; Kschischo, M.; Jones, N.P.; East, P.; Nicke, B.; Spassieva, S.; et al CERT Depletion Predicts Chemotherapy Benefit and Mediates Cytotoxic and Polyploid-Specific Cancer Cell Death through Autophagy Induction. J. Pathol. 2012, 226, 482-494. [CrossRef]

245. Sonoda, Y.; Yamamoto, D.; Sakurai, S.; Hasegawa, M.; Aizu-Yokota, E.; Momoi, T.; Kasahara, T. FTY720, a Novel Immunosuppressive Agent, Induces Apoptosis in Human Glioma Cells. Biochem. Biophys. Res. Commun. 2001, 281, 282-288. [CrossRef]

246. Zheng, T.; Meng, X.; Wang, J.B.; Chen, X.; Yin, D.; Liang, Y.; Song, X.; Pan, S.; Jiang, H.; Liu, L. PTEN- and P53-Mediated Apoptosis and Cell Cycle Arrest by FTY720 in Gastric Cancer Cells and Nude Mice. J. Cell. Biochem. 2010, 111, 218-228. [CrossRef]

247. Zhang, N.; Qi, Y.; Wadham, C.; Wang, L.; Warren, A.; Di, W.; Xia, P. FTY720 Induces Necrotic Cell Death and Autophagy in Ovarian Cancer Cells: A Protective Role of Autophagy. Autophagy 2010, 6, 1157-1167. [CrossRef]

248. Azuma, H.; Takahara, S.; Horie, S.; Muto, S.; Otsuki, Y.; Katsuoka, Y. Induction of Apoptosis in Human Bladder Cancer Cells In Vitro and In Vivo Caused by FTY720 Treatment. J. Urol. 2003, 169, 2372-2377. [CrossRef] [PubMed]

249. Yasui, H.; Hideshima, T.; Raje, N.; Roccaro, A.M.; Shiraishi, N.; Kumar, S.; Hamasaki, M.; Ishitsuka, K.; Tai, Y.T.; Podar, K.; et al. FTY720 Induces Apoptosis in Multiple Myeloma Cells and Overcomes Drug Resistance. Cancer Res. 2005, 65, 7478-7484. [CrossRef]

250. Min, K.-J.; Kwon, T.K. Induction of Lysosomal Membrane Permeabilization Is a Major Event of FTY720-Mediated Non-Apoptotic Cell Death in Human Glioma Cells. Cancers 2020, 12, 3388. [CrossRef]

251. Li, C.X.; Yang, X.X.; Wang, H.W.; Li, X.C.; Ng, K.T.-P.; Lo, C.M.; Man, K. FTY720 Suppresses Liver Tumor Growth and Metastasis by Reducing Circulating Regulating T Cells and Enhancing the Anti-Tumor Effect of Rapamycin. Oncotargets Ther. 2020, 13, 4743-4754. [CrossRef] [PubMed]

252. Salinas, N.R.A.; Oshima, C.T.F.; Cury, P.M.; Cordeiro, J.A.; Bueno, V. FTY720 and Lung Tumor Development. Int. Immunopharmacol. 2009, 9, 689-693. [CrossRef]

253. Suzuki, S.; Li, X.K.; Enosawa, S.; Shinomiya, T. A New Immunosuppressant, FTY720, Induces Bcl-2-Associated Apoptotic Cell Death in Human Lymphocytes. Immunology 1996, 89, 518-523. [CrossRef] [PubMed]

254. Yoshino, T.; Tabunoki, H.; Sugiyama, S.; Ishii, K.; Kim, S.U.; Satoh, J.I. Non-Phosphorylated FTY720 Induces Apoptosis of Human Microglia by Activating SREBP2. Cell. Mol. Neurobiol. 2011, 31, 1009-1020. [CrossRef]

255. Pchejetski, D.; Bohler, T.; Brizuela, L.; Sauer, L.; Doumerc, N.; Golzio, M.; Salunkhe, V.; Teissié, J.; Malavaud, B.; Waxman, J.; et al. FTY720 (Fingolimod) Sensitizes Prostate Cancer Cells to Radiotherapy by Inhibition of Sphingosine Kinase-1. Cancer Res. 2010, 70, 8651-8661. [CrossRef] [PubMed]

256. Hait, N.C.; Avni, D.; Yamada, A.; Nagahashi, M.; Aoyagi, T.; Aoki, H.; Dumur, C.I.; Zelenko, Z.; Gallagher, E.J.; Leroith, D.; et al. The Phosphorylated Prodrug FTY720 Is a Histone Deacetylase Inhibitor That Reactivates ER $\alpha$ Expression and Enhances Hormonal Therapy for Breast Cancer. Oncogenesis 2015, 4, e156. [CrossRef] [PubMed]

257. di Pardo, A.; Maglione, V. Sphingolipid Metabolism: A New Therapeutic Opportunity for Brain Degenerative Disorders. Front. Neurosci. 2018, 12, 249. [CrossRef] 
258. Chatzakos, V.; Rundlöf, A.K.; Ahmed, D.; de Verdier, P.J.; Flygare, J. Inhibition of Sphingosine Kinase 1 Enhances Cytotoxicity, Ceramide Levels and ROS Formation in Liver Cancer Cells Treated with Selenite. Biochem. Pharmacol. 2012, 84, 712-721. [CrossRef] [PubMed]

259. Zhang, J.; Zhang, C.; Hu, L.; He, Y.; Shi, Z.; Tang, S.; Chen, Y. Abnormal Expression of MiR-21 and MiR-95 in Cancer Stem-like Cells Is Associated with Radioresistance of Lung Cancer. Cancer Investig. 2015, 33, 165-171. [CrossRef]

260. Huang, X.; Taeb, S.; Jahangiri, S.; Emmenegger, U.; Tran, E.; Bruce, J.; Mesci, A.; Korpela, E.; Vesprini, D.; Wong, C.S.; et al. MiRNA-95 Mediates Radioresistance in Tumors by Targeting the Sphingolipid Phosphatase SGPP1. Cancer Res. 2013, 73, 6972-6986. [CrossRef] 